\title{
Compaction control on diagenesis and reservoir quality development in red bed sandstones: a case study of Permian Rotliegend sandstones
}

\author{
Alexander C. Monsees ${ }^{1}$ D $\cdot$ Benjamin Busch ${ }^{1} \cdot$ Christoph Hilgers $^{1}$
}

Received: 26 October 2020 / Accepted: 5 April 2021 / Published online: 22 April 2021

(c) The Author(s) 2021

\begin{abstract}
Authigenic minerals formed during diagenesis in conjunction with compaction by burial have long been known to lead to porosity-loss of sandstones, and a subsequent deterioration in reservoir quality. The diagenetic impact on reservoir quality and permeability heterogeneity measured horizontal and vertical to bedding was characterized in three fluvio-eolian Lower Permian Rotliegend outcrops from the Flechtingen High, the northern Hesse Basin (both Germany) and the Vale of Eden (UK) using point-counting, polarized light-microscopy, helium pycnometry and permeability measurements. Results show significant porosity (10 to $35 \%)$ and permeability $(0.01$ to $10,000 \mathrm{mD})$ ranges largely independent of depositional environment. The major control on reservoir quality in Cornberg Sandstones are dolomite and siderite cementation in conjunction with illitization and illite and kaolinite cementation, leading together with quartz cementation to a mostly cemented IGV and poorest reservoir quality (avg. horizontal permeability: $0.96 \mathrm{mD}$ ). Flechtingen Sandstones are most intensely compacted due to the lack of significant early diagenetic cement phases and continuous illitic grain-to-grain coatings, which inhibited intense quartz cementation but enhanced chemical compaction at quartz grain contacts, resulting in intermediate reservoir quality (avg. horizontal permeability: $34.9 \mathrm{mD}$ ). Penrith Sandstones lack significant authigenic phases besides quartz due to carbonate dissolution during uplift. They show the least amount of detrital feldspars and clay minerals, leading to no major reservoir quality reduction by burial diagenetic clay mineral alterations, resulting in the highest reservoir quality (avg. horizontal permeability: $5900 \mathrm{mD}$ ). Additional results highlight higher horizontal to vertical permeability ratios $k_{\mathrm{h}} / k_{\mathrm{v}}$ in less homogeneous sandstones of $<10 \mathrm{mD}$ of 10 , and in more homogenous, higher permeable sandstones $>1000 \mathrm{mD}$ of 1 . Although detrital and authigenic sample compositions vary throughout the studied areas, the general effect of grain coatings coverages on syntaxial cement inhibition and chemical compaction can be delineated. This study increases the understanding of porosity reduction in sandstones, as it confirms the necessity to differentiate between the illitic grain-to-grain coatings and illitic grain-to-IGV coatings. As a result, the enhancing effect of illite on chemical compaction on quartz grain-grain boundaries can be better constrained, as well as the effect of grain coatings on quartz cementation. This is relevant for reservoir quality and risk assessment in hydrocarbon and geothermal plays as well as in storage.
\end{abstract}

Keywords Sandstone $\cdot$ Rotliegend $\cdot$ Reservoir quality $\cdot$ Diagenesis $\cdot$ Permeability

\section{Introduction}

Siliciclastic sandstone reservoirs are hosting about $60 \%$ of the world's hydrocarbons (Bjørlykke and Jahren 2010) and are thus of significant economic interest. The utilization of such reservoirs have been extended beyond hydrocarbon

Alexander C. Monsees

alexander.monsees@kit.edu

1 Department Structural Geology and Tectonics, Institute for Applied Geosciences, Karlsruhe Institute of Technology (KIT), Adenauerring 20a, 76131 Karlsruhe, Germany extraction in the past two decades, being used for geothermal energy exploration (Caulk and Tomac 2017; Heap et al. 2017), hydrogen storage (Henkel et al. 2013; Pfeiffer et al. 2017), or $\mathrm{CO}_{2}$ sequestration (Ambrose et al. 2008; Barnes et al. 2009; Benson and Cole 2008; Heinemann et al. 2012). After deposition as sand, mechanical and chemical compaction induce the consolidation process to sandstone during diagenesis over geological timescales (Greene et al. 2009; Houseknecht 1987; Kristiansen et al. 2011; Lundegard 1992). Diagenesis affects the rock's porosity and permeability, and its viability as a reservoir (Morad et al. 2010; Taylor et al. 2010; Wadsworth et al. 2016). Sandstones experience diagenetic alterations during 
burial; these are related to the initial detrital composition and grain coating minerals (Aagaard et al. 2000; Busch et al. 2020; Monsees et al. 2020a), fluid type, -chemistry and -pressure (Bjørlykke and Høeg 1997; Gaupp et al. 1993), thermal exposure over time (Becker et al. 2019; Busch et al. 2018; Lander et al. 2008), and faults controlling temperature-overprint by hydrothermal fluid circulation (Farrell and Healy 2017; Farrell et al. 2014; Wüstefeld et al. 2017).

Monsees et al. (2020a) proposed grain-coatings to be a controlling factor on cementational and compactional behavior of Lower Permian Rotliegend sandstones natural gas reservoir in the North German Basin. The aim of this study is to test if the observed controls on chemical compaction by grain-to-grain coatings and of grain-to-intergranular volume coatings on quartz cementation can also be delineated in similar settings with variable source areas and burial paths. Therefore, study areas have been constrained to depositional parameters (terrestrial, fluvio-eolian sandstones) and ages (Rotliegend, Lower Permian) similar to the boundary conditions presented by Monsees et al. (2020a). Samples were collected from the Cornberg Formation in Cornberg, Hesse, Germany, the Mirow and Parchim Formations in Bebertal, Saxony-Anhalt, Germany, and the Penrith Sandstone Formation near Penrith, Cumbria, UK. Results may highlight, that in addition to vertical effective stresses during burial, the presence of (a) mechanical, and (b) chemical compactionenhancing illite controls the compactive behavior of reservoir sandstones. This case study is highlighting the heterogeneous effect of diagenetic overprint on the petrophysical parameters porosity and permeability of three exhumed Permian sandstone lithologies located in Germany and the UK, which were deposited in similar fluvio-eolian depositional environments, while source areas and depositional ages vary. The complex relationship between cementation and compaction will be assessed and its impact on reservoir quality will be determined. Heterogeneities from permeability measurements conducted parallel to bedding compared to permeability normal to bedding will be quantitatively constrained. Insights gained from this study will help to assess the variability of diagenetic alterations in sandstones of similar depositional settings and might improve quantitative constraints applicable in subsurface reservoir quality assessment for hydrocarbon exploration, geothermal energy, hydrogen storage, and $\mathrm{CO}_{2}$ sequestration.

\section{Geological setting}

\section{Cornberg Sandstones}

Cornberg Sandstones (CS) belong to the uppermost Rotliegend (Lower Permian) lithostratigraphic unit (Kowalczyk et al. 2012), which is also referred to as the Weißliegend
(Paul 2012). The Cornberg Formation crops out in Cornberg quarry (Quarry A) in the Nentershäuser Basin, which is a sub-basin of the Hesse Basin in central Germany (Kulick et al. 1984) (Fig. 1). The Nentershäuser Basin has been interpreted as a pull-apart basin due to its thickness increase of Rotliegend deposits from tens to hundreds of meter over lateral distances $<10 \mathrm{~km}$ (Kowalczyk et al. 2012; Kulick et al. 1984). Based on meter-scale cross-bedded strata, the depositional system of the sandstones have been controversially discussed (Gast 1994; Pryor 1971; Schumacher 1985). Recent studies interpret them to be of eolian origin due to the distinct cross-bedding and tetrapod tracks (Gast 1994; Haubold et al. 1995; Kowalczyk et al. 2012). The thickness of the formation in the outcrop is up to $20 \mathrm{~m}$ (Kowalczyk et al. 2012), being conformably overlain by the Kupferschiefer claystone marking the onset of the Zechstein transgression (Kowalczyk et al. 2012), and underlain by gray, sandy conglomerates and red conglomeratic sandstones and pelites (Aehnelt and Katzung 2007). Therefore, Cornberg Sandstones represent the uppermost Rotliegend below the Zechstein base (Fig. 2), which is defined by the Kupferschiefer claystone (Menning et al. 2011; Paul 2012). A published burial model for Cornberg Sandstones is not available, however, Rotliegend burial models $170 \mathrm{~km}$ further north show burial to more than 4-5 km maximum burial depth (Fig. 1d, burial curve i) until the Upper Cretaceous inversion (Schwarzer and Littke 2007). Inversion likely took place from Late Cretaceous onwards, as described for other Permian exposures in Central Germany (Kley and Voigt 2008).

\section{Flechtingen Sandstones}

Upper Rotliegend fluvio-eolian Flechtingen Sandstones (FS) are exposed in the Schwentesius quarry (Quarry B) $1 \mathrm{~km}$ north of Bebertal, Saxony-Anhalt, Germany, and in a decommissioned quarry $1 \mathrm{~km}$ southwest of Bebertal, (Quarry C, Fig. 1), located on the margins of the Flechtingen High (Gaitzsch et al. 2004). The Flechtingen High is a NW-SE striking structural high uplifted during the Upper Cretaceous inversion (Kley and Voigt 2008; Otto 2003). The extent of the Flechtingen High is limited by the Haldensleben thrust fault to the NE and the Aller lineament to the SW, which belongs to the Elbe-Fault zone. Rotliegend sedimentary rocks exposed around Bebertal are commonly used as analogs for the North German Rotliegend hosted hydrocarbon reservoirs (Gast et al. 2010; Schröder et al. 1995). The Rotliegend sandstones exposed near Bebertal are equivalent to the Mirow Formation and Parchim Formation of the Havel Subgroup based on regional stratigraphic correlations (Gaitzsch et al. 2004; Schneider and Gebhardt 1993). Therefore, their absolute sedimentation age is 266 to $262 \mathrm{Ma}$ (Menning 1995). The total thickness of the Havel subgroup equivalent exposed on the Flechtingen 


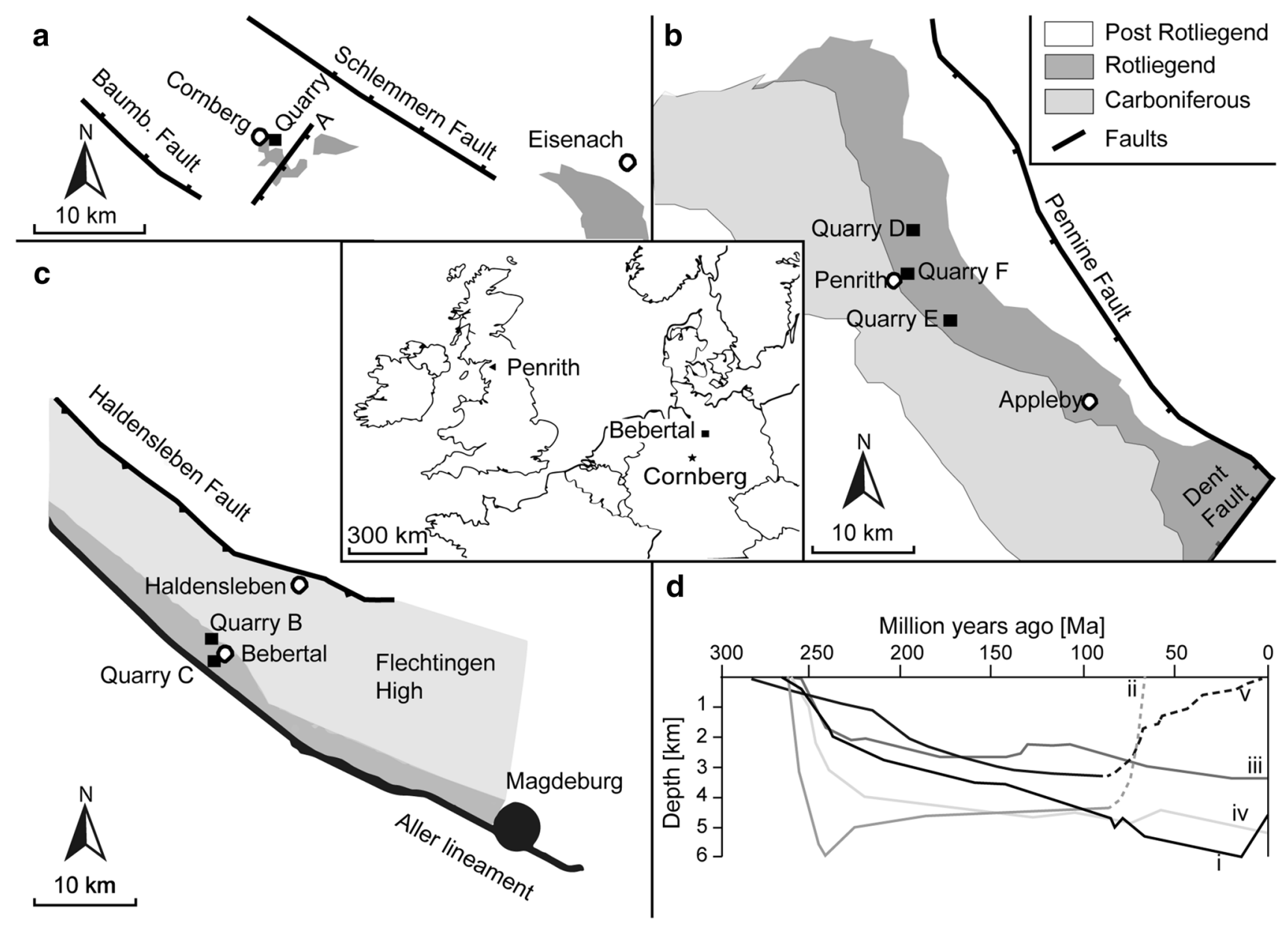

Fig. 1 Schematic geological maps of the vicinity of the studied quarries. a Extent of Rotliegend deposits in the northern Hesse Basin, redrawn from Kowalczyk et al. (2012). Fault orientation and kinematics based on Motzka-Nöring et al. (1987). b Present-day geology of the Vale of Eden highlighting the extent of Rotliegend deposits, redrawn from Turner et al. (1995) and modified with fault kinematics and orientations taken from Underhill et al. (1988) and Woodcock et al. (2008). c Geology of the Flechtingen High, showing the location of fluvio-eolian Rotliegend marginal deposits. Surface geology

High amounts to roughly $160 \mathrm{~m}$ (Gaitzsch et al. 1995). The Havel subgroup is unconformably underlain by the Müritz subgroup and the Altmark subgroup and unconformably overlain by dominantly fluvio-eolian sandstones of the Elbe subgroup (Gaitzsch et al. 2004) (Fig. 2). For Flechtingen Sandstones, a burial model based on thermal data proposed by Fischer et al. (2012) shows a rapid burial reaching over $200^{\circ} \mathrm{C}$ in the early Triassic. Their resulting burial depth of approximately $6 \mathrm{~km}$ assumes a normal geothermal gradient of $35^{\circ} \mathrm{C} / \mathrm{km}$ (Fig. 1d, burial curve ii). Inversion was initiated in the late Cretaceous (Fischer et al. 2012). The burial model proposed by Kohlhepp (2012) (well Peckensen $780 \mathrm{~km}$ NNE of Bebertal) agrees with rapid initial subsidence during the Upper Permian, with maximum burial depth for Upper Rotliegend proposed to be at $3 \mathrm{~km}$ for Rotliegend redrawn from Fischer et al. (2012) and modified with fault orientation and kinematics adapted from Kley and Voigt (2008), Otto (2003) and Scheck et al. (2002). The Aller Lineament is not indicated as a normal fault, as it consists of several graben faults with a strike-slip component (Lohr et al. 2007). d Burial models for the respective study areas, compiled from published research. i: Northern German Basin (Schwarzer and Littke 2007), ii: Flechtingen High (Fischer et al. 2012), iii: Altmark basin margin (Kohlhepp 2012), iv: Altmark basin center (Kohlhepp 2012), v: Penrith Formation (Turner et al. 1995)

deposits at the basin margin (Fig. 1d, burial curve iii) or $5 \mathrm{~km}$ at the basin center (Fig. 1d, burial curve iv) before upper Cretaceous inversion (Kohlhepp 2012).

\section{Penrith Sandstones}

Permian Penrith Sandstones (PS) crop out in the Vale of Eden half graben, Cumbria, UK (Fig. 1), covering an area of approximately $48 \times 6 \mathrm{~km}$ (Busch et al. 2017; Macchi 1981; Turner et al. 1995). Penrith Sandstones were studied in Bowscar quarry (Quarry D) $3 \mathrm{~km}$ north of Penrith, in the Salter Hill outcrop (Quarry E) $5 \mathrm{~km}$ southeast of Penrith, and in Penrith Beacon outcrop (Quarry F) $1 \mathrm{~km}$ northeast of Penrith (Fig. 1). The extent of the Vale of 


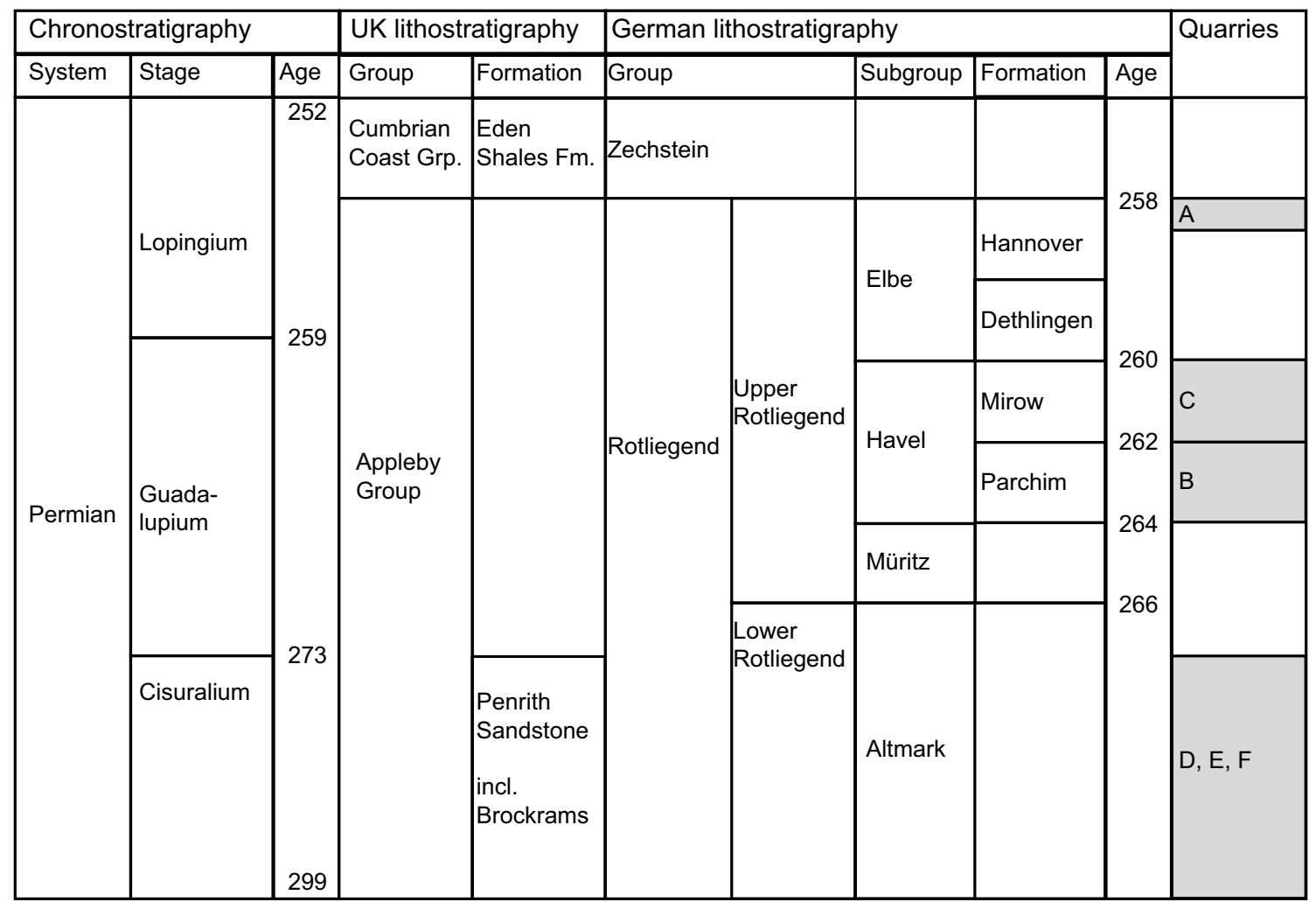

Fig. 2 Stratigraphic overview of the studied sandstones. Subgroups and formations compiled from BGS (2020), Gaitzsch et al. (1995), Kowalczyk et al. (2012) and Paul (2012). Ages in million years. The

Eden is limited by the Pennine Mountains to the east, the Dent fault system to the south, and the Lake District complex to the west (Fig. 1). The Appleby Group consists of the eolian Penrith Formation and basal alluvial deposits locally referred to as the Brockram facies (Macchi 1981) and is time-equivalent to the Central European Rotliegend (Jackson et al. 1997) (Fig. 2). The total thickness of the Penrith Sandstone is discussed to reach between $100 \mathrm{~m}$ (BGS 2020) and up to $1 \mathrm{~km}$ in the subsurface towards the East Irish Sea (Turner et al. 1995). Upper Carboniferous siliciclastic rocks in the northern Vale of Eden and Lower Carboniferous limestones in the south are unconformably overlain by the Appleby Group (Arthurton and Wadge 1981; Macchi 1981; Turner et al. 1995). The Appleby Group is conformably overlain by shales, evaporites and dolomite of the Zechstein, which are combined in the Eden Shales Formation (Arthurton and Wadge 1981). Penrith Sandstones were buried during the late Paleozoic, reaching a thermal maximum of $120^{\circ} \mathrm{C}$ in the early Cretaceous at approximately 3-4 km burial depth (Fig. 1d, burial curve v), before upper Cretaceous inversion took place (Turner et al. 1995). chronostratigraphic ages and subdivision were taken from Cohen et al. (2013), while ages for regional lithostratigraphic groups are based on Menning (1995)

\section{Materials and methods}

Rock samples were taken from quarries and plugs were drilled parallel to bedding for petrographic analysis, as well as normal and parallel to bedding for petrophysical analysis. A total of 41 thin-sections originating from each of the three main studied sandstones Cornberg Sandstone $(n=9,1$ outcrop, Fig. 1, Table 1), Flechtingen Sandstone $(n=15,2$ outcrops, Fig. 1, Table 1), and Penrith Sandstone ( $n=17,3$ outcrops, Fig. 1, Table 1) were analyzed. The thin sections were impregnated with a blue-dyed epoxy resin to highlight porosity. Thin-sections are prepared to a thickness of $30 \mu \mathrm{m}$ and in some cases stained with a combined Alizarin Red S and potassium ferricyanate solution in $0.5 \% \mathrm{HCl}$ to aid the identification of carbonate minerals.

Grain sizes were determined on 100 grains with image analysis using ImageJ (Becker et al. 2017). Skewness and sorting were determined based on grain size measurements after Trask (1930). Point-counting (300 counts) was performed on a grid adjusted to the maximum grain size with a semi-automated Pelcon Point Counter installed on a Leitz Aristomet microscope. The statistical error of point-counting data was determined population-based by dividing the standard deviation by the square root of the number of samples 
Table 1 Sample overview, listing quarry or outcrop names, their abbreviations used in the text, latitude and longitude, their study area, and the respective sample quantity and sample type

\begin{tabular}{|c|c|c|c|c|c|c|c|}
\hline Quarry/outcrop name & $\begin{array}{l}\text { Quarry } \\
\text { abbreviation }\end{array}$ & Quarry location $\left[{ }^{\circ}\right]$ & Study area & $\begin{array}{l}n \\
\text { Thin-sections }\end{array}$ & $\begin{array}{l}n \\
\text { Total plugs }\end{array}$ & $\begin{array}{l}n \\
\text { Horizon- } \\
\text { tal plugs }\end{array}$ & $\begin{array}{l}n \\
\text { Vertical plugs }\end{array}$ \\
\hline Cornberg quarry & A & 51.0423869 .865660 & Cornberg & $9(8)$ & 19 & 10 & 9 \\
\hline Schwentesius quarry & B & 52.25433811 .337711 & Flechtingen & $8(2)$ & 3 & 2 & 1 \\
\hline Decommissioned quarry & $\mathrm{C}$ & 52.23143311 .319722 & Flechtingen & $7(6)$ & 22 & 11 & 11 \\
\hline Bowscar quarry & $\mathrm{D}$ & $\begin{array}{l}54.701049 \\
-2.746095\end{array}$ & Penrith & $13(12)$ & 22 & 13 & 9 \\
\hline Salter Hill outcrop & $\mathrm{E}$ & $\begin{array}{l}54.630138 \\
-2.647602\end{array}$ & Penrith & $2(1)$ & 7 & 4 & 3 \\
\hline Penrith Beacon outcrop & $\mathrm{F}$ & $\begin{array}{l}54.675278 \\
-2.735556\end{array}$ & Penrith & $2(1)$ & 2 & 1 & 1 \\
\hline Total & - & - & - & $41(30)$ & 75 & 41 & 34 \\
\hline
\end{tabular}

Values in brackets in row " $n$ Thin sections" represent the amount of available horizontal plugs directly corresponding to these individual thinsections

(Becker et al. 2017). Average occurrence rates below 0.3\% were referred to as in traces. Sandstone compositions were classified after Folk (1980). The intergranular volume (IGV) was classified according to Paxton et al. (2002) as the sum of the intergranular pore space, intergranular cement, and detrital matrix. Compactional porosity loss, cementational porosity loss, and compactional indices were calculated after Lundegard (1992). The value for the compactional index ranges between zero (porosity lost exclusively to cementation) and one (porosity lost exclusively to compaction). The percentage of clay mineral coatings on grain-to-IGV (GTI) interfaces was assessed on at least 50 grains per sample (Busch et al. 2020). Percentages of illite coatings on grain-to-grain (GTG) detrital quartz interfaces were evaluated after Monsees et al. (2020a) by microscopy-aided image analysis. Microporosity in clays was estimated based on quantitative electron microscopy data on different clay mineral data sets (Hurst and Nadeau 1995). The abundance of clay minerals was multiplied with the amount of microporosity as determined by Hurst and Nadeau (1995) for illite $(63 \pm 10 \%)$, kaolinite $(43 \pm 11 \%)$ and clay clasts $(10 \pm 3 \%)$.

Petrophysical measurements were performed on cylindrical plugs ( $2.54 \mathrm{~cm}$ diameter, $4 \mathrm{~cm}$ length), and therefore are within the guidelines for petrophysical measurements on sandstones recommended by Heap (2019). In total, 75 plugs were prepared: 19 plugs for the Cornberg Sandstone, 25 plugs for the Flechtingen sandstone, and 31 plugs for the Penrith Sandstone (Table 1). In total 30 horizontal plugs directly correspond to thin sections (Table 1). Samples were dried in a vacuum oven at $40^{\circ} \mathrm{C}$ and $0.1 \mathrm{bar}$ for at least $72 \mathrm{~h}$ prior to the petrophysical measurements. Helium porosity $(\varphi)$ was measured with an AccuPyc II 1340 pycnometer, measuring the connected porosity (Becker et al. 2017). The porosity values given here are the average of ten measurement cycles per sample. Permeability $(\kappa)$ was measured on 75 plugs with an air permeameter (measurement range 0.001 to $10,000 \mathrm{mD}, 1 \mathrm{mD} \triangleq 9.869 * 10^{-16} \mathrm{~m}^{2} \approx$ $10^{-15} \mathrm{~m}^{2}$ ) manufactured by Westphal Mechanik using oilfree lab air as the permeant $\left(80 \% \mathrm{~N}_{2}, 20 \% \mathrm{O}_{2}\right)$. Laminarflow conditions are determined during the measurement by the software used to operate the permeability cell, ensuring that all measurements were taken under laminar-flow conditions and thus do not require a Forchheimer correction (Whitaker 1996). A constant confining pressure of $1.2 \mathrm{MPa}$ was applied to the samples throughout the measurement, which was applied two minutes before the measurement was conducted at ambient laboratory temperature $\left(T=22^{\circ} \mathrm{C}\right)$ and until steady-state flow conditions were achieved. Permeability values are Klinkenberg-corrected (Klinkenberg 1941).

\section{Results}

\section{Petrography}

\section{Texture}

Eolian Cornberg Sandstones are deposited as decimeter thick, cross-bedded dunes (Fig. 3a), partly showing Liesegang rings in outcrops. On the plug scale, they show bed-size-dependent grain-size variations from fine to medium sand (Fig. 3b) (avg.: $0.32 \pm 0.2 \mathrm{~mm}$, range: $0.24-0.48 \mathrm{~mm}$ ) with well rounded and moderately well to very well sorting (Fig. 3c, supplementary material).

Fluvio-eolian Flechtingen Sandstones are deposited as stacked fluvial channels, and eolian dunes intercalating with sheet sands (Fig. 3d). Their bedding planes on the plug scale are not very clearly pronounced (Fig. 3e), showing 

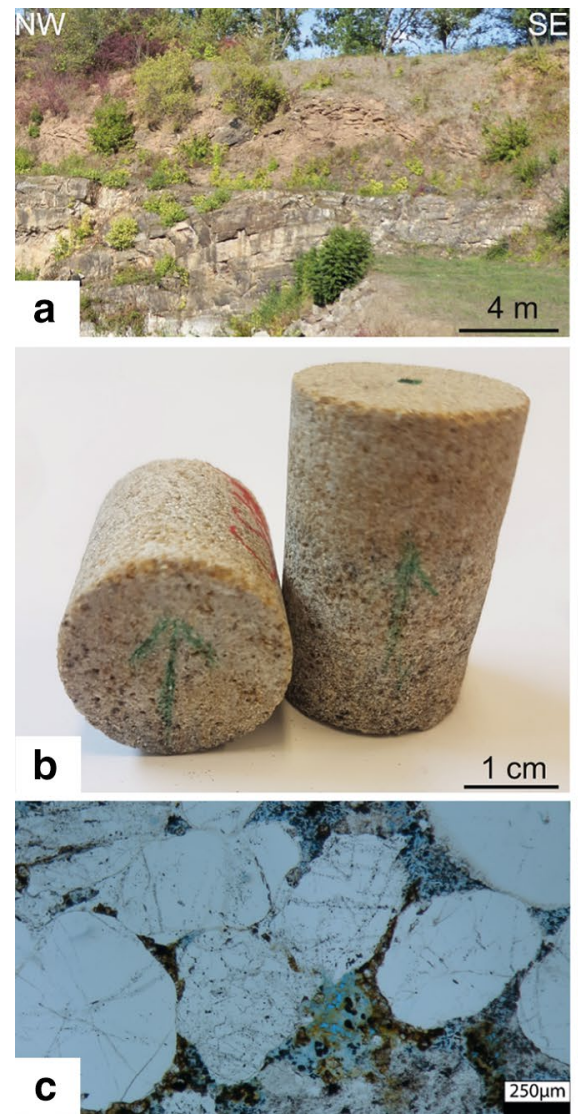
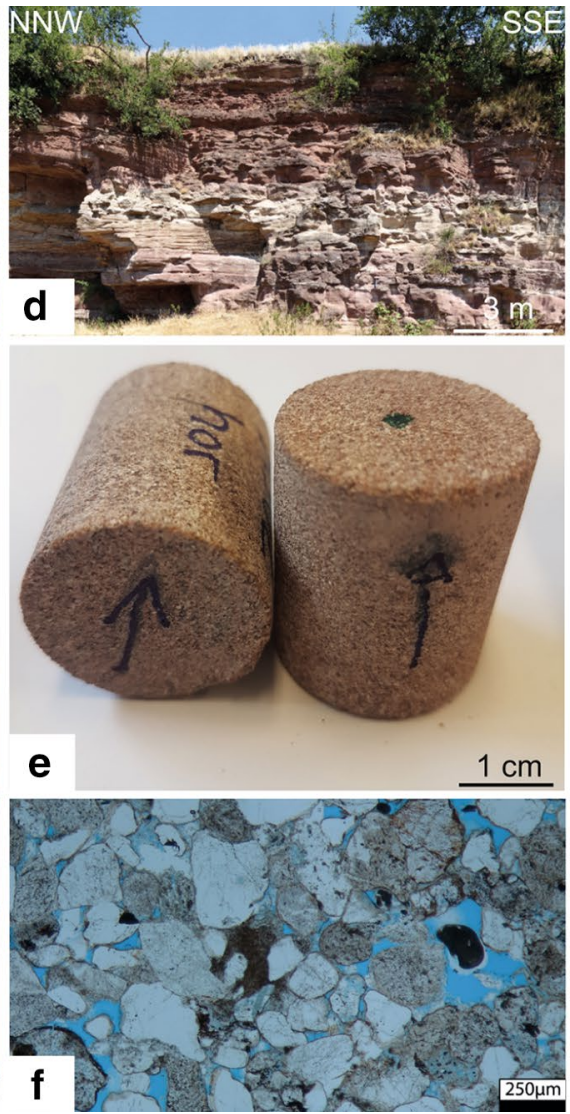
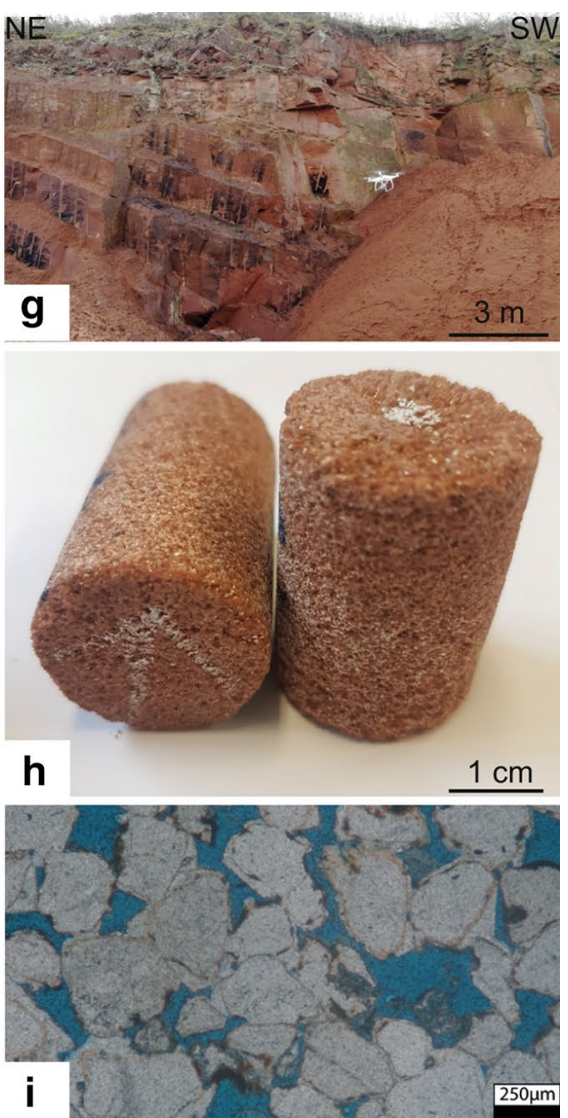

Fig. 3 Overview over the studied sandstones by study location from meter scale (a, $\mathbf{d}, \mathbf{g})$ over $\mathrm{cm}$ scale $(\mathbf{b}, \mathbf{e}, \mathbf{h})$ to $\mu \mathrm{m}$ scale $(\mathrm{c}, \mathbf{f}, \mathbf{i})$, sorted in rows by location. Here, Cornberg sandstone is shown in quarry A

subrounded to rounded grains (Fig. 3f). Their median grain size ranges from fine to medium sand, averaged to finemedium sand (avg.: $0.29 \pm 0.02 \mathrm{~mm}$, range: $0.17-0.43 \mathrm{~mm}$ ), and their sorting is moderately well to very well (supplementary material).

Eolian Penrith Sandstones are very homogenous dune deposits, characterized by cross-bedded red sandstones on the outcrop scale (Fig. 3g) and pronounced cm-thick beds with seemingly repeating grain-size variations. On the plug scale, the bedding planes are barely recognizable due to homogeneity within one of the grain size classes (Fig. 3h). The grain size ranges from fine-medium sand to fine coarse sand, and averages to medium sand (avg.: $0.42 \pm 0.02 \mathrm{~mm}$, range: $0.28-0.55 \mathrm{~mm}$ ) (supplementary material). The grains are subrounded (Fig. 3i), and the sorting of the detrital grains is well to extremely well in quarries $\mathrm{D}$ and $\mathrm{E}$, and moderately well in quarry $\mathrm{F}$ (supplementary material).

\section{Detrital composition}

The sandstone classification results in three groups based on the three study areas (Fig. 4). Cornberg Sandstones are (images a-c), Flechtingen sandstone is shown in quarry $\mathrm{C}$ (images $\mathbf{d}-\mathbf{f}$ ), and Penrith sandstone is shown in quarry D (images $\mathbf{g}-\mathbf{i}$ )

classified as quartzarenites to sublitharenites, Flechtingen Sandstones show a less mature composition of lithic arkoses, feldspathic litharenites and subarkoses, while Penrith Sandstones are similarly mature as Cornberg Sandstones, however showing a larger quantity of feldspars compared to rock fragments, resulting in the classification as quartzarenites to subarkoses (Fig. 4). There are no differences in compositions for samples originating from the same study area, but from different quarries (Fig. 4).

The most abundant detrital mineral in all samples and study areas is detrital quartz (Fig. 5a). The sum of monocrystalline (Fig. 5a), polycrystalline (Fig. 5b, d) and undulose detrital quartz ranges from 54.0 to $67.0 \%$ in Cornberg Sandstones (avg.: $62.8 \pm 1.4 \%$ ), from 42.0 to $60.7 \%$ in Flechtingen Sandstones (avg.: $51.7 \pm 1.3 \%$ ) and from 53.0 to $74.3 \%$ in Penrith Sandstones (avg.: $62.0 \pm 1.4 \%$ ). Rock fragments (RF) were classified as metamorphic RF (Fig. 5c, d) sedimentary RF (Fig. 5e), volcanic RF (Fig. 5), plutonic RF, undifferentiated RF, and chert (Fig. 5b). Rock fragments are the second most abundant detrital constituent in Cornberg Sandstones ranging from 4.7 to $8.7 \%$ (avg.: $6.4 \pm 0.2 \%$ ), while rock fragments are the third most abundant detrital 
Fig. 4 Ternary sandstone classification after Folk (1980). F: feldspar, Q: quartz, R: rock fragments. Quarries: A-Cornberg, B and C-Flechtingen, D to F-Penrith

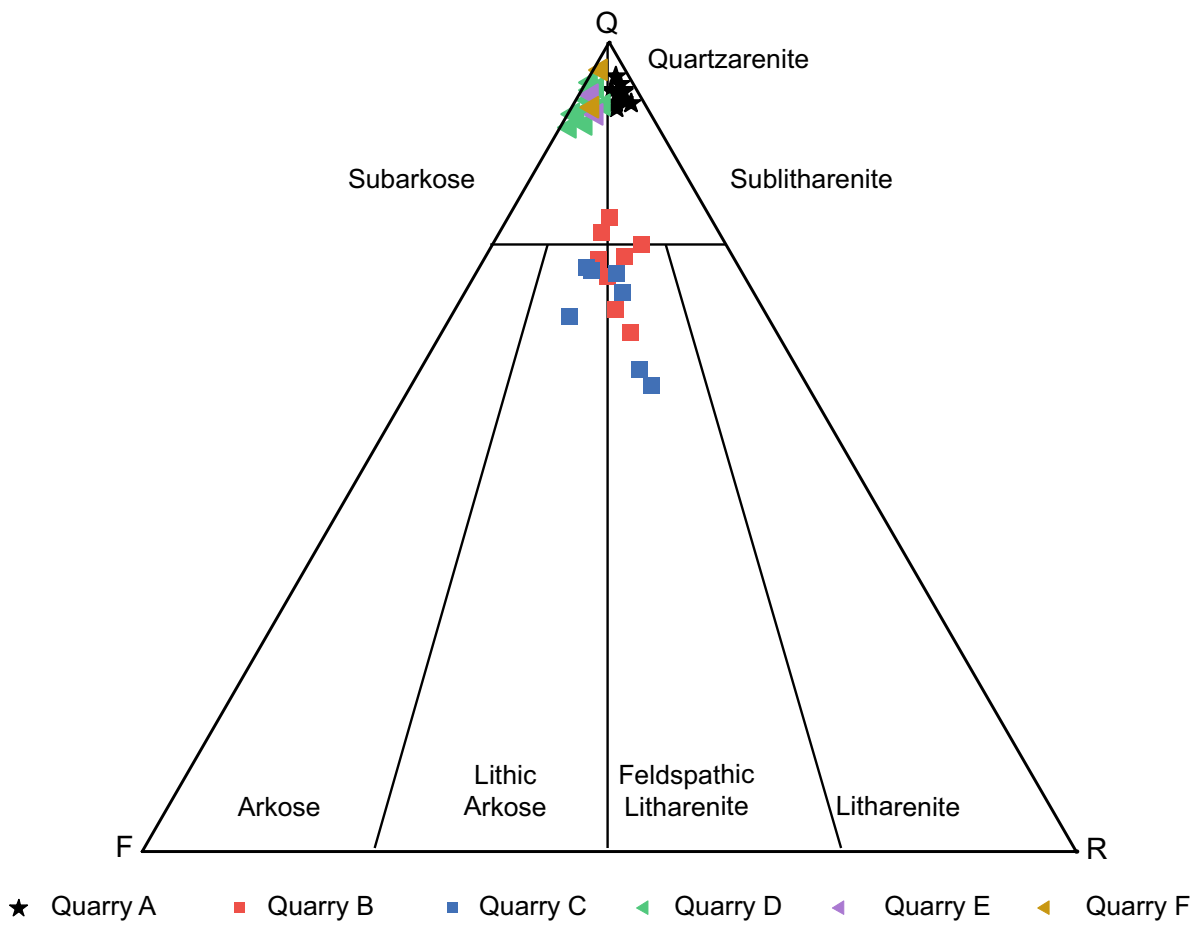

constituent in Flechtingen Sandstones ranging from 15.3 to 31.7\% (avg.: 20.3 $\pm 1.1 \%$ ) and in Penrith Sandstones ranging from 1.0 to $4.3 \%$ (avg.: $2.5 \pm 0.2 \%$ ) (supplementary material). Potassium feldspars (Fig. 5a) and plagioclases (Fig. 5b) are the third most abundant detrital constituent in Cornberg Sandstones with a range of 2.0 to $4.7 \%$ (avg.: $3.1 \pm 0.2 \%$ ), while feldspars are the second most abundant detrital constituent in Flechtingen Sandstones ranging from 15.7 to 27.0\% (avg.: $20.9 \pm 0.7 \%$ ) and Penrith Sandstones with a range of 4.0 to $12.0 \%$ (avg.: $8.6 \pm 0.7 \%$ ). The fourth group of detrital constituents is the accessory minerals and matrix, including mica, zircon and hornblende. Accessories were encountered consistently in Cornberg Sandstones (avg.: $1.1 \pm 0.1 \%$ ), while they are very rare in Flechtingen Sandstones (avg.: $0.5 \pm 0.2 \%$ ), and only found in traces in some Penrith Sandstone samples (avg.: $0.1 \pm 0.0 \%$ ).

\section{Authigenic composition}

Cornberg Sandstone The most abundant authigenic mineral in Cornberg Sandstones are quartz cements (avg.: $8.1 \pm 0.6 \%$ ) ranging from 6.0 to $11.3 \%$. The second most abundant authigenic minerals are carbonates, comprised of dolomite and siderite (avg. 5.8 $\pm 1.4 \%$ ), showing a high sample variability in occurrence from 0.7 to $15.0 \%$. The third most common authigenic component is pore-filling illite (avg.: $5.7 \pm 1.1 \%$ ), ranging from 2.3 to $12.3 \%$. Additional authigenic phases include illite replacements of potassium feldspars (avg.: 2.6 $\pm 0.4 \%$ ), iron hydroxides and oxides (avg.: $1.8 \pm 0.3 \%$ ), pore-filling kaolinite (avg.: $1.4 \pm 0.4 \%$ ), authigenic rutile (avg.: $1.3 \pm 0.3 \%$ ), dolomite replacements of potassium feldspar (avg.: $1.0 \pm 0.2 \%$ ), kaolinite replacements of potassium feldspar (avg.: $0.9 \pm 0.3 \%$ ), pore-lining illite (avg.: $0.7 \pm 0.2 \%$ ), and pore-lining iron oxides (avg.: $0.3 \pm 0.1 \%$ ). Illite replacements of potassium feldspar were encountered in traces (supplementary material).

In Cornberg Sandstones, detrital grains are occasionally covered by tangential illitic grain coatings (Fig. 6a). The detrital grains, which are predominately quartz, are commonly overgrown by syntaxial quartz cements (Fig. 6a), and in contact with siderite, pore-filling illite (Fig. 6a), and dolomite. Detrital grains show long to concavo-convex grain contacts (Fig. 5d, e). Rhombohedral siderite was observed to overgrow quartz cements (Fig. 6a), while dolomite encompassed several detrital grains directly in a patchy, poikilotopic texture maintaining floating to point contacts (Fig. 6b). Pore-filling illite was observed to overgrow dolomite, siderite and quartz cements (Fig. 6a), also encompassing authigenic rutile (Fig. 6c). Kaolinite was observed to overgrow quartz cements (Fig. 6c). Amorphous iron hydroxides were observed in relatively large patches, overgrowing quartz and dolomite cements and clay mineral cements (Fig. 6c). The majority of detrital feldspar was observed to have been replaced by illite (Fig. 6d).

Flechtingen Sandstone In Flechtingen Sandstones, quartz

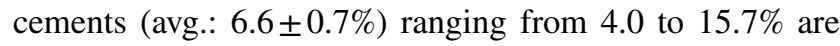
the most common authigenic mineral. The second most abundant authigenic mineral is pore-lining-illite (avg. $5.0 \pm 0.5 \%$ ), showing sample variability in occurrence from 

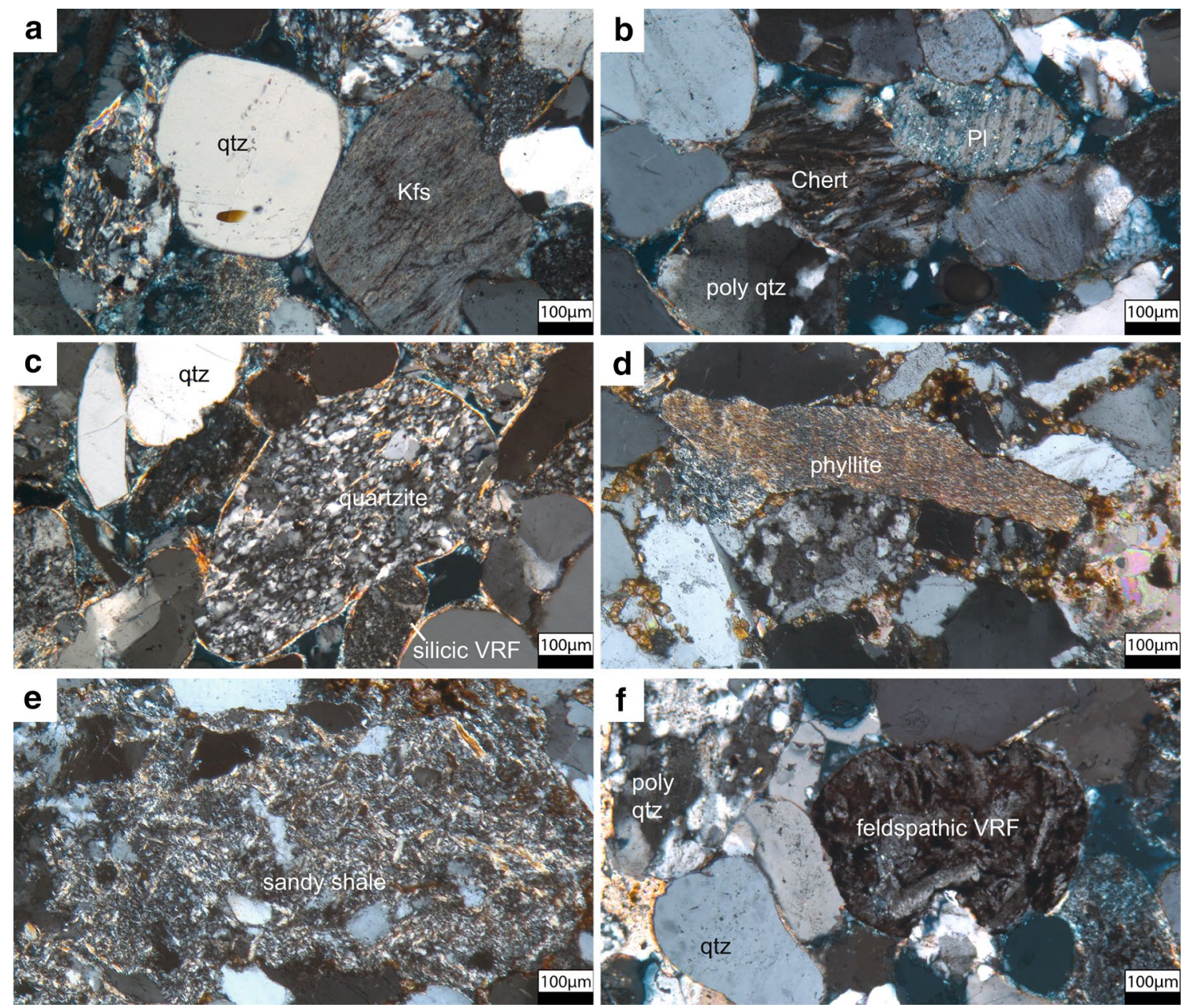

Fig. 5 Thin-section images in cross-polarized light of detrital components encountered in the studied samples. qtz quartz, Kfs potassium feldspar, $P l$ Plagioclase, poly q $t z$ polycrystalline quartz, $V R F$ volcanic rock fragment

2.0 to $11.3 \%$. The third most common authigenic component are illite replacements of potassium feldspar (avg.: $1.5 \pm 0.2 \%$ ), ranging from 0.0 to $4.0 \%$. Additional authigenic phases include feldspar cements (avg.: $1.4 \pm 0.2 \%$ ), samplespecific occurring calcite (avg.: $1.2 \pm 0.5 \%$ ), pore-lining iron oxides (avg.: $0.8 \pm 0.1 \%$ ), iron hydroxides and oxides (avg.: $0.9 \pm 0.2 \%$ ) and pore-filling illite (avg.: $0.4 \pm 0.1 \%$ ). Calcite replacements of feldspars, pore-filling kaolinite, kaolinite replacements of feldspars, radial illite, barite and authigenic rutile were encountered in traces (supplementary material).

Detrital grains in Flechtingen Sandstones are encased by illitic grain coatings, occasionally stained red by hematite (Fig. 6e), mostly showing concavo-convex to sutured grain contacts (Fig. 5b, c, f). Rarely, pigmented pore-lining iron oxide grain coatings occur instead of pore-lining illitic grain coatings. Pigmented iron oxide coatings show the same textural relationships like illite coatings with the exception of being directly overgrown by quartz cements. In absence of illite or iron oxide grain coatings or at sites with an incomplete grain coating coverages, detrital quartz grains are overgrown by euhedral quartz cements (Fig. 6e). Calcite cements occur only in some samples as patchy poikilotopic phase, encompassing detrital grains independent of their composition maintaining floating to point contacts (Fig. 6f). Detrital feldspars, if not encompassed by illite coatings, are overgrown by syntaxial feldspar cements (Fig. 6g). Two feldspar cement phases can be identified based on textural relations; phase I encompasses the detrital feldspar, while phase II encompasses phase I feldspar cements (Fig. 6g). A second calcite phase overgrowing quartz and feldspar overgrowth cements rarely occurs in individual samples (Fig. 6h).

Penrith Sandstone The most abundant authigenic mineral in Penrith Sandstones is quartz cements (avg.: $12.8 \pm 1.0 \%$ ) ranging from 5.0 to $19.3 \%$. The second most abundant authigenic mineral is pore-lining illite (avg. $1.7 \pm 0.2 \%$ ), ranging from 0.7 to $3.7 \%$. The third most common authigenic component are pore-lining iron oxides (avg.: $0.7 \pm 0.1 \%$ ), rang- 
ing from 0.0 to $2.0 \%$. Additional authigenic phases include illite replacements of potassium feldspars (avg.: $0.5 \pm 0.1 \%$ ), pore-filling iron hydroxides and oxides (avg.: $0.4 \pm 0.1 \%$ ), pore-filling illite (avg.: $0.3 \pm 0.2 \%$ ), and authigenic rutile (avg.: $0.3 \pm 0.1 \%$ ). Kaolinite replacements of feldspar, porefilling kaolinite, feldspar cements, and illite replacements of kaolinite were encountered in traces (supplementary material).

The detrital grains of Penrith Sandstones are mostly encompassed by iron oxide grain coatings (Fig. 6i) or porelining illitic grain coatings (Fig. 6j). Grain contacts range from floating to point contacts (Fig. 3i) to point to long contacts (Fig. 5i). Similar to the Flechtingen Sandstones, detrital quartz coated in pigmented iron oxides are overgrown by quartz cements, which have reached or are approaching euhedral form (Fig. 6i, j), while continuous illitic grain coatings inhibited quartz cementation (Fig. 6j). Rhombohedral husks in quartz cements can be encountered occasionally (Fig. 6i), which hints the occurrence of a cement phase, that has been dissolved and now occurs as porosity.

Optical porosity Optical porosities are generally lowest in Cornberg Sandstones (Fig. 3c, avg.: 1.5\%), and highest in Penrith Sandstones (Fig. 3i, avg.: 15.1\%), while Flechtingen Sandstones show lower to intermediate optical porosities (Fig. 3f, avg.: 4.8\%). Intergranular porosity is the largest contributor to optical porosity in all study areas, however with different relative fractions; roughly $90 \%$ of optical porosities in Penrith Sandstones are due to intergranular porosities (supplementary material). In Cornberg Sandstones, intergranular porosities account for roughly $75 \%$ of all optical porosity, while intergranular porosity in Flechtingen Sandstones contributes only about $60 \%$ to optical porosity (supplementary material). The remainder of optical porosity is due to isolated intragranular or intracrystalline porosity (Fig. 5b, Fig. 6i) in altered feldspars, rock fragments or dissolved cement phases.

Compaction Cornberg Sandstones experienced a nearly complete loss of their initial porosity due to intense porefilling cementation and compaction, with compaction being the slightly more important factor (Fig. 7a). Flechtingen Sandstones show a compaction-induced porosity loss leading to a porosity reduction of about $5 \%$ (Fig. 7a), with quarries $\mathrm{B}$ and $\mathrm{C}$ showing a comparable range of values. Porosity loss in Penrith Sandstone was the least severe and was slightly dominated by compactional porosity loss (Fig. 7a). Quarry F seems to be an exception for Penrith Sandstones, showing higher compaction and less porosity (Fig. 7a). These results are also reflected in the Houseknecht diagram, showing almost all of the IGV in Cornberg Sandstones being occupied by cement, generally smaller IGVs in Flechtingen Sandstones with lower cement volumes and higher porosities than in Cornberg Sandstones, and highest IGVs and porosities in Penrith Sandstones (Fig. 7b).

Grain coatings The dominant grain-coating phase in the studied sandstones is illite (Fig. 6a, f, j, supplementary material). Generally, Cornberg sandstones show the lowest grainto-IGV (GTI) coating coverage of illite (avg.: $24.0 \pm 2.6 \%$ ), followed by Penrith Sandstones, (avg.: $28.3 \pm 3.3 \%$ ) while Flechtingen Sandstones show the largest average GTI coating coverage (avg.: $54.3 \pm 3.6 \%$ ) (Fig. 8a, supplementary material). Samples with higher GTI coating coverages show less authigenic quartz, while samples with less GTI coating coverage show larger amounts of quartz cements (Fig. 8a). This negative correlation $\left(R^{2}=0.55\right)$ seems to be more clearly demonstrated in Penrith and Flechtingen Sandstones than in Cornberg Sandstones (Fig. 8a). Quarry F shows higher GTI coating coverages than the other Penrith Sandstone samples (Fig. 8a). The grain-to-grain (GTG) coating coverage is highest in Flechtingen Sandstones (avg.: $35.9 \pm 2.4 \%$ ) and lowest in Penrith Sandstones (avg.: 15.5 $\pm 1.7 \%$ ) (Fig. 8b). Higher amounts of GTG coatings coincide with generally lower intergranular volumes $\left(R^{2}=0.56\right.$, Fig. $\left.8 b\right)$.

\section{Petrophysics}

Helium porosity ranges from 3.9 to $36.2 \%$ (avg.: 19.3\%) for all samples, while permeability of all samples ranges from 0.002 to $>10,000 \mathrm{mD}$ (avg.: $2155 \mathrm{mD}$ ) (Fig. 9, supplementary material).

Separated by study area, Cornberg and Flechtingen Sandstones show comparable average porosities of $14.4 \%$ (range: 9.1 to $19.9 \%$ ) and $14.3 \%$, respectively (range: 7.7 to $21.3 \%$ ), while Penrith Sandstones show the highest average porosities of $26.4 \%$ (range: 19.6 to 36.2\%) (Fig. 9). Permeabilities of Cornberg Sandstones are lowest (avg.: $0.52 \mathrm{mD}$, range: 0.002 to $8.6 \mathrm{mD}$ ), Flechtingen Sandstones have intermediate permeabilities (avg.: $27.9 \mathrm{mD}$, range: 0.03 to $190 \mathrm{mD}$ ), and Penrith Sandstones have very high permeabilities (avg.: $5192 \mathrm{mD}$, range: 48 to $>10,000 \mathrm{mD}$ ) (Fig. 9a). Generally, higher helium porosity correlates with higher permeability (Fig. 9a). Outliers from this are Cornberg Sandstones and samples with permeabilities above 10,000 $\mathrm{mD}$ (Fig. 9a).

Grouped by the studied quarry, an apparently different porosity-permeability relationship from quarry B to quarry C in Flechtingen Sandstones is identified (Fig. 9a). Sandstones in quarry B show comparable permeabilities to sandstones in quarry $\mathrm{C}$, although their porosities are 6 to 8\% lower (Fig. 9a). The porosity-permeability relationship in quarries D-F follows the same gradient, however quarry E represents only the higher range of observed values and quarry F only the lower range, while quarry D shows the 

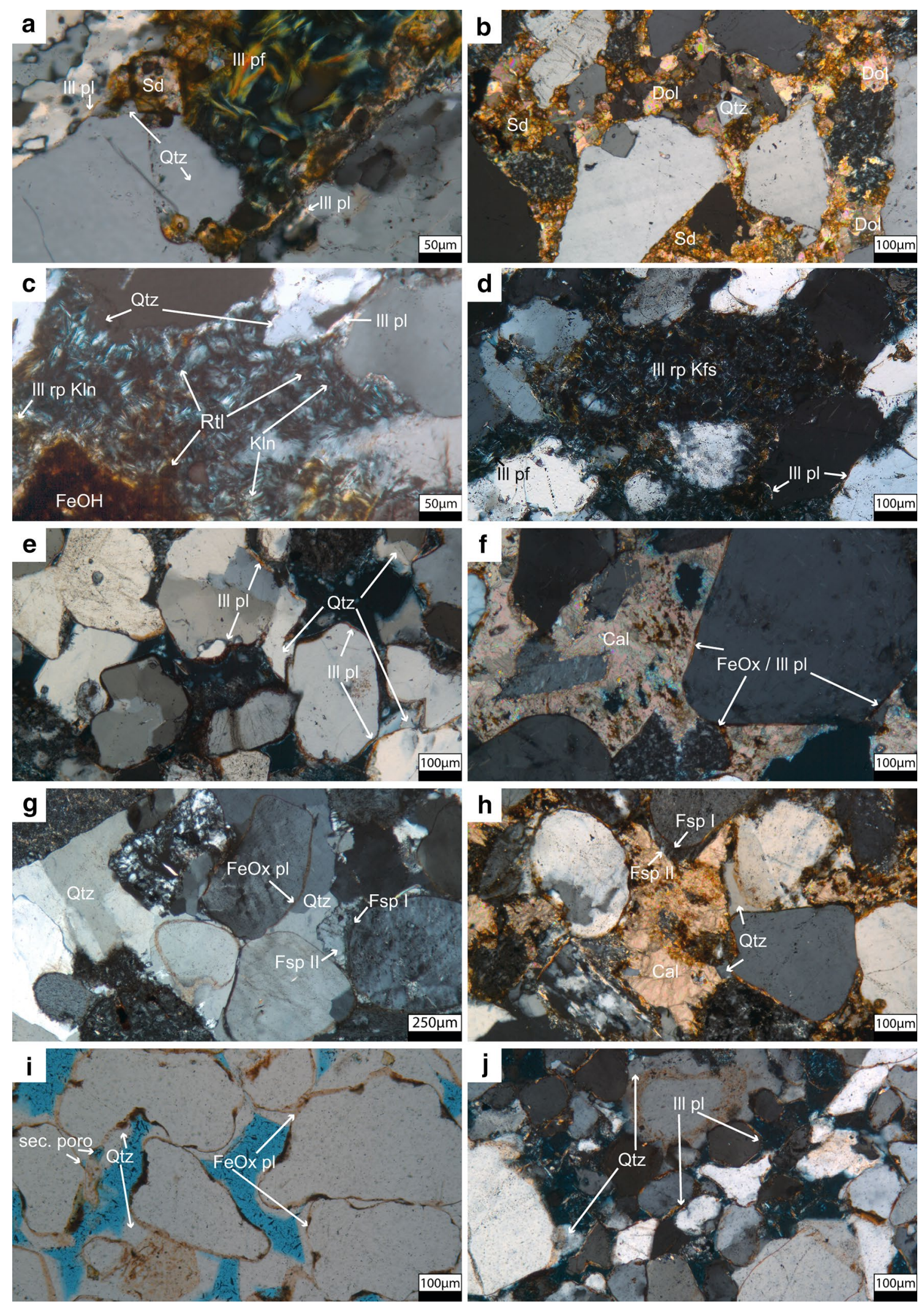
4Fig. 6 Thin-section images under cross-polarized light (xpl, images $\mathbf{a}-\mathbf{h}, \mathbf{j}$ ) and plain-polarized light (ppl, image i) of authigenic minerals encountered in the study areas. Porosity is colored in blue in ppl images and very dark blue in xpl images. a-d: Cornberg Sandstones, e-h: Flechtingen Sandstones, $\mathbf{i}-\mathbf{j}$ : Penrith Sandstones. $p l$ pore-lining, $p f$ pore filing, $\mathrm{Sd}$ siderite, $\mathrm{Qtz}$ quartz, $\mathrm{Dol}$ dolomite, $\mathrm{FeOH}$ iron hydroxides, Rtl rutile, $K l n$ kaolinite, $I l l$ illite, $K f s$ potassium feldspar, $\mathrm{Cal}$ calcite, $\mathrm{Fsp}$ feldspar, $\mathrm{RF}$ rock fragment, $\mathrm{FeOx}$ iron oxides, $\mathrm{Sec}$ poro secondary porosity due to dolomite dissolution

whole range of measured porosity and permeability data in Penrith Sandstones (Fig. 9a).

The depositional system does not exhibit a consistent control on the porosity and permeability of the studied sandstones (Fig. 9b). Both the highest and lowest porosities and permeabilities were measured in dune sandstones, with permeabilities ranging from 0.002 to $>10,000 \mathrm{mD}$ and helium porosities ranging from 9 to $39 \%$ (Fig. 9). Fluvial sandstones, encountered only in quarry $\mathrm{C}$, range from 0.03 to 100 $\mathrm{mD}$ in permeability and 8 to $22 \%$ in porosity (Fig. $9 \mathrm{~b}$ ). Sheet sands show the narrowest permeability range and porosity range from 0.05 to $4 \mathrm{mD}$ and 7 to $12 \%$, however, they were also the least abundant depositional system $(N=5$, Fig. 9 b).

Permeabilities of plugs drilled parallel to bedding are almost exclusively higher than vertical permeabilities (Fig. 10). The offset between the permeability difference is smaller for higher permeabilities. Plugs with horizontal permeabilities above $100 \mathrm{mD}$ consistently show a reduction in vertical permeability of less than a factor of 5 (Fig. 10). If horizontal permeabilities are below $100 \mathrm{mD}$, vertical permeabilities are reduced by a factor of 5 or larger (Fig. 10).

\section{Influence of petrographic properties on petrophysical parameters}

\section{Grain size and sorting}

The effect of detrital grain size on permeability and helium porosity is indistinct when considering all data points, with grain sizes around 0.3 to $0.4 \mathrm{~mm}$ showing permeabilities ranging from 0.01 to over $1000 \mathrm{mD}$ and helium porosities ranging from below 10 to 25\% (Fig. 11a). Considering the study areas individually, Cornberg Sandstones show larger grain sizes of 0.3 to $0.4 \mathrm{~mm}$ in less porous $(<15 \%$ He porosity) and less permeable $(<0.1 \mathrm{mD})$ samples, while grain sizes of 0.2 to $0.3 \mathrm{~mm}$ coincide with helium porosities above $15 \%$ and permeabilities above $0.1 \mathrm{mD}$ (Fig. 11a). Flechtingen Sandstones show no correlation between grain size and porosity or permeability (Fig. 11a). Larger grain sizes in Penrith Sandstones above $0.5 \mathrm{~mm}$ coincide with permeabilities above $10,000 \mathrm{mD}$ and porosities around $30 \%$, however, smaller grain sizes also feature comparably permeable samples up to $10,000 \mathrm{mD}$ (Fig. 11a). The permeability and porosity range in Penrith Sandstones around or below
$1000 \mathrm{mD}$ and $25 \%$ is exclusively showing grain sizes below $0.4 \mathrm{~mm}$ (Fig. 11a).

Better sorted sandstones seem to show a tendency towards higher porosities and permeabilities (Fig. 11b). This relationship is clearest in Penrith Sandstones, where better sorting of 1.3 or below results in permeabilities of at least $1000 \mathrm{mD}$, while all samples below $1000 \mathrm{mD}$ show sorting around 1.4 or higher (Fig. 11b). The effect of sorting in Cornberg Sandstones on permeability and porosity is indistinct, as there is only one data point with slightly worse than average sorting in the lower permeability ranges (Fig. 11b). Flechtingen Sandstones show no consistent correlation between sorting and permeability or porosity (Fig. 11b).

\section{Optical porosity, IGV and compaction}

Optical porosity shows a positive correlation with permeability and helium porosity (Fig. 11c). In all samples, optical porosity is much lower than helium porosity. This contrast is particularly obvious in Cornberg Sandstones with optical porosities as low as $10 \%$ of their corresponding helium porosity, while optical porosities in Flechtingen Sandstones amount to approximately $30 \%$ of helium porosity, whereas optical porosities in Penrith Sandstones are approximately $50 \%$ of helium porosity (Fig. 11c). Flechtingen Sandstones and Cornberg Sandstones show similar helium porosity, but Flechtingen Sandstones show higher optical porosity, also showing a consistent trend with the less porous samples of Penrith Sandstones, which have the highest optical porosity (Fig. 11c).

Intergranular volume (IGV) shows no correlation with neither permeability nor helium porosity (Fig. 11d). IGV has no distinct relation to helium porosity or permeability in Cornberg and Flechtingen Sandstones. Most of the lowest IGVs in Penrith Sandstones occur in the least porous and least permeable samples, however, there are also samples with permeabilities around $10,000 \mathrm{mD}$ with similarly low IGVs for Penrith Sandstones (Fig. 11d). The compactional index shows no consistent correlation regarding porosity or permeability, neither for all samples nor study area-based (Fig. 11e).

\section{Clay mineral coatings}

Illitic grain-to-IGV (GTI) coatings show no correlation to helium porosity or permeability (Fig. 11f). There are no clear correlations visible within the Cornberg and Flechtingen Sandstones either, however, GTI coatings coverage seems to be generally higher in less permeable and less porous samples of Penrith Sandstones, barring one outlier (Fig. 11f).

Illitic grain-to-grain (GTG) coatings are the least abundant in highly permeable and porous samples (Fig. 11g). 
a

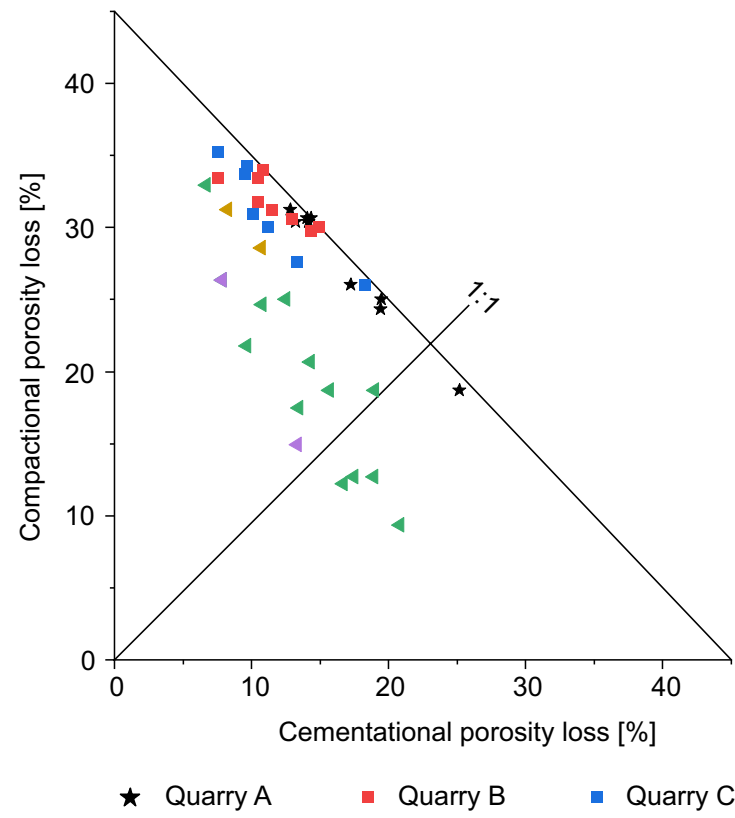

Fig. 7 a Porosity loss diagram after Lundegard (1992), illustrating the relative amount of relative porosity caused by cementation (abscissa) and compaction (ordinate). The data shows no clear distinction for the porosity loss process by study area. Almost no porosity was preserved in Cornberg sandstones, intermediate amounts of porosity were preserved in Flechtingen sandstones, and highest amounts of porosity were preserved in Penrith sandstones. b Houseknecht diagram Houseknecht (1987), plotting the cement volume

Cornberg Sandstones show a slight increase in the abundance of GTG coatings towards less permeable and less porous specimen (Fig. 11g). This trend cannot be observed in Flechtingen Sandstones, where no correlation between GTG coatings and permeability or porosity is apparent (Fig. 11g). Penrith Sandstones show no correlation either, however lowest GTG coatings are often coinciding with higher permeabilities and porosity specimen (Fig. 11g).

\section{Cements and clay microporosity}

Considering all data points, samples with higher abundances in quartz cement show higher permeability and helium porosity (Fig. 11h). In Cornberg Sandstones, this trend cannot be observed. Instead, the specimen with the highest amount of quartz cement shows among the lowest permeabilities and porosities (Fig. 11h). Flechtingen Sandstones show no correlation between quartz cements and permeability or porosity (Fig. 11h), while the highly porous and permeable specimen in Penrith Sandstones show a tendency towards higher quartz cements abundance (Fig. 11h).

\section{b}

\section{Cement volume [\%]}

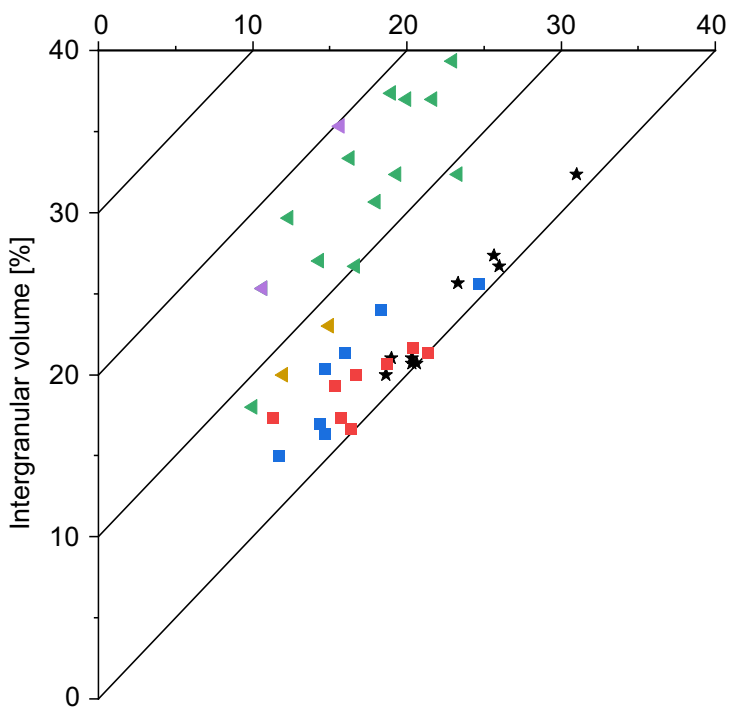

$\triangleleft$ Quarry D 4 Quarry E $\triangleleft$ Quarry F

on the abscissa versus the intergranular volume (IGV, as defined by Paxton et al. (2002)) on the ordinate. Cornberg sandstones show high IGV and high cements, and low porosity, Flechtingen sandstones show less IGV, less cements and slightly higher porosity, and Penrith sandstones show the highest IGVs and intermediate cement volumes with the highest porosities. Quarries: A-Cornberg, B and CFlechtingen, D to F-Penrith

Carbonate cements only occur in a limited number of samples, mostly within Cornberg Sandstones and some Flechtingen Sandstones, which show lower permeabilities and porosities than the samples with less or no carbonate cements (Fig. 11i).

The abundance of all clay minerals (sum of all authigenic clay minerals, clay mineral replacements, detrital matrix and shale rock fragments) shows a negative correlation with permeability and helium porosity over the whole population (Fig. 11j), being lowest in the most permeable/porous specimen. Study area based, however, there is no distinguishable trend (Fig. 11j). The impact on permeability and porosity is clearer when clays and carbonate cements are considered together (Fig. 11k).

Microporosity was calculated based on the point-counted amount of all clay minerals. As these are of predominately illitic composition (supplementary material), a microporosity of illite of $60 \%$ (Hurst and Nadeau 1995) was used to quantify the total amount of microporosity in clays and their impact on permeability and helium porosity (Fig. 111). Microporosities are lower in higher permeable and more porous samples (Fig. 111), and vice-versa. There are no clear 


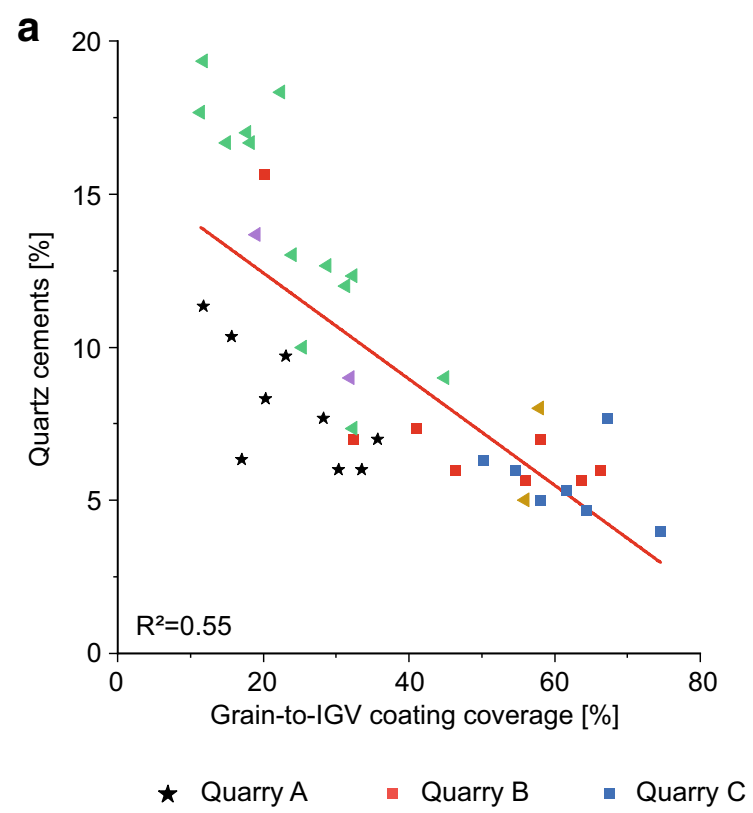

Fig. 8 a Grain-to-IGV (GTI) coating coverage on the abscissa versus quartz cements on the ordinate. Flechtingen sandstones show highest GTI coating coverage and lowest quartz cements, while Penrith sandstones show lowest GTI coating coverage, but the highest amount of quartz cements. Cornberg sandstones show intermediate quartz cements and GTI coating coverage. b Grain-to-grain (GTG)

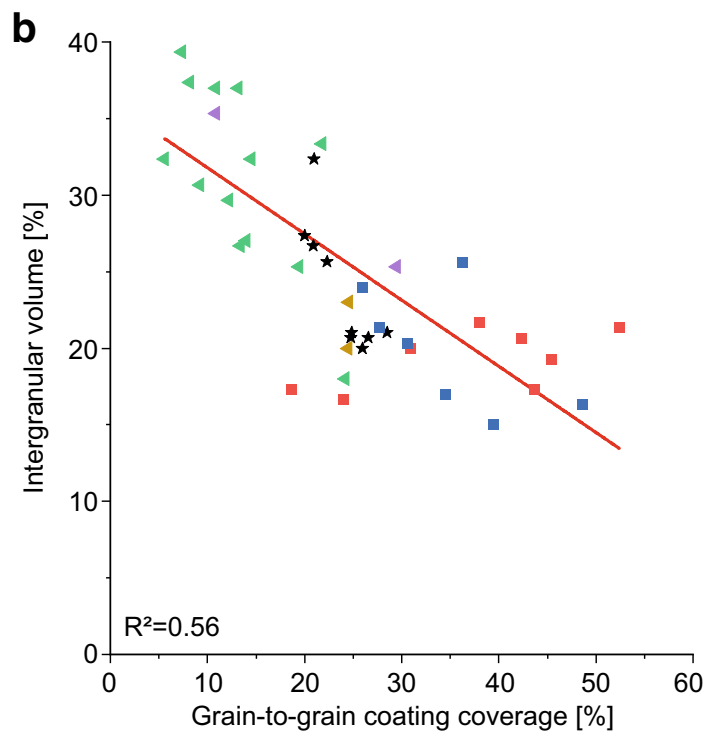

$\triangleleft$ Quarry D 4 Quarry E $\triangleleft$ Quarry F a

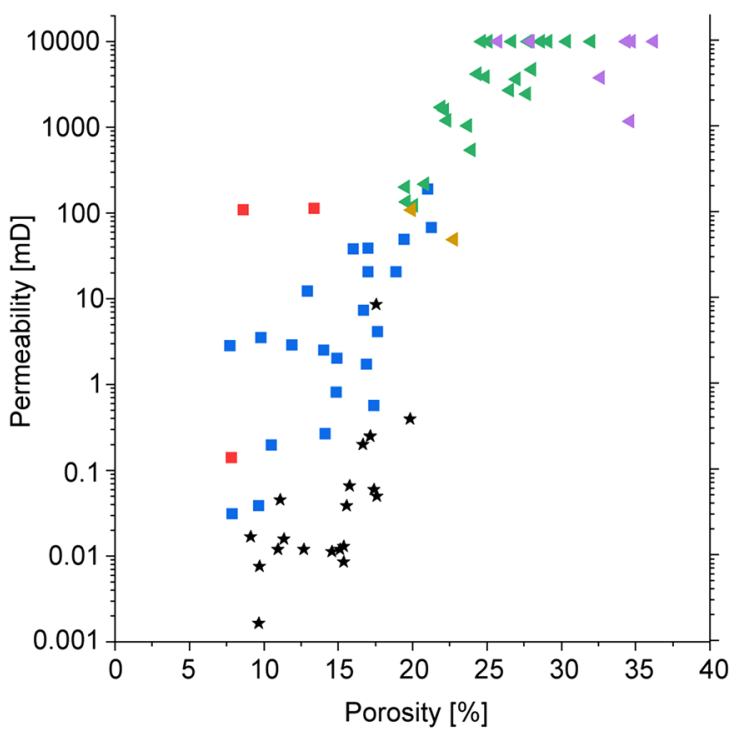

b

coating coverage on the abscissa versus intergranular volume (IGV). Flechtingen sandstones show highest GTG coatings and lowest IGVs, Cornberg sandstones show intermediate GTG coatings and IGVs, and Penrith sandstones show lowest GTG coatings but highest IGVs. Quarries: A-Cornberg, B and C-Flechtingen, D to F-Penrith

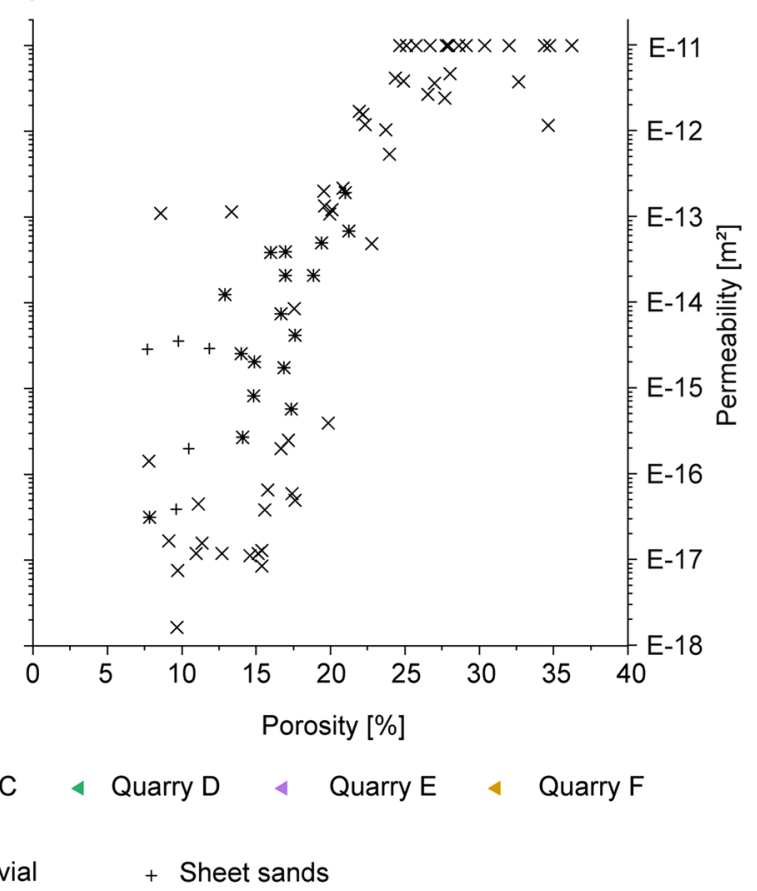

Fig. 9 Porosity determined by helium pycnometry (abscissa) versus Klinkenberg-corrected air permeability at $1.2 \mathrm{MPa}$ confining pressure (ordinate) plotted on logarithmic scaling. The upper measurement limit of the permeability cell is $10000 \mathrm{mD}\left(=9.869 \mathrm{e}-12 \mathrm{~m}^{2}\right)$. Cornberg sandstones show the lowest porosities and permeabilities,
Flechtingen sandstones show intermediate porosities and permeabilities, and Penrith sandstones show the highest porosities and permeabilities. Helium porosity (abscissa) and permeability (ordinate) categorized by quarry (a) and by depositional system (b). Quarries: $\mathrm{A}$-Cornberg, B and C-Flechtingen, D to F-Penrith 


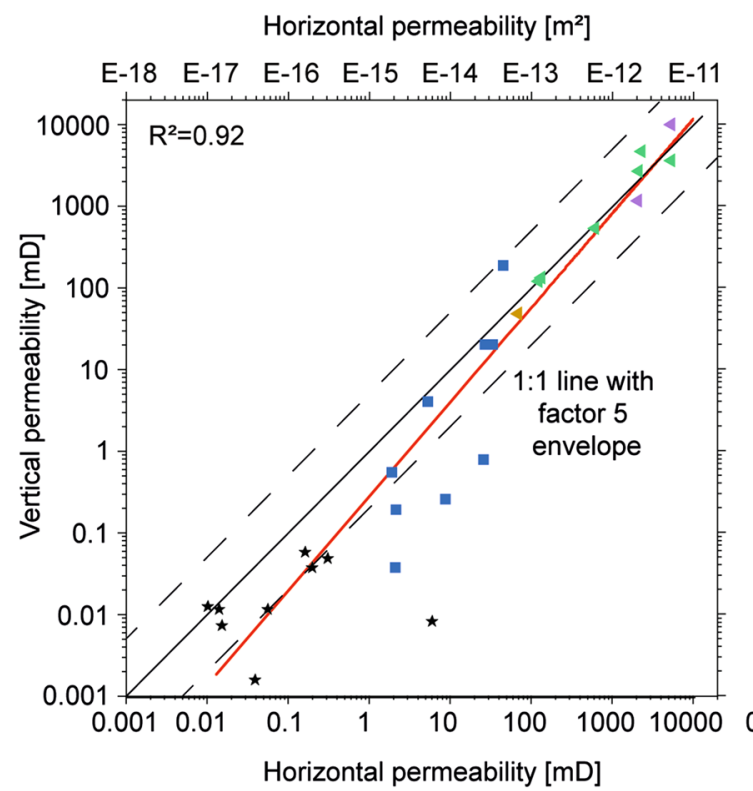

$\star$ Quarry A

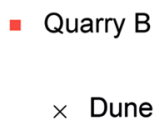

$\times$ Dune

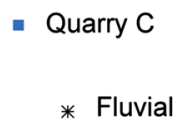

* Fluvial
Horizontal permeability $\left[\mathrm{m}^{2}\right]$
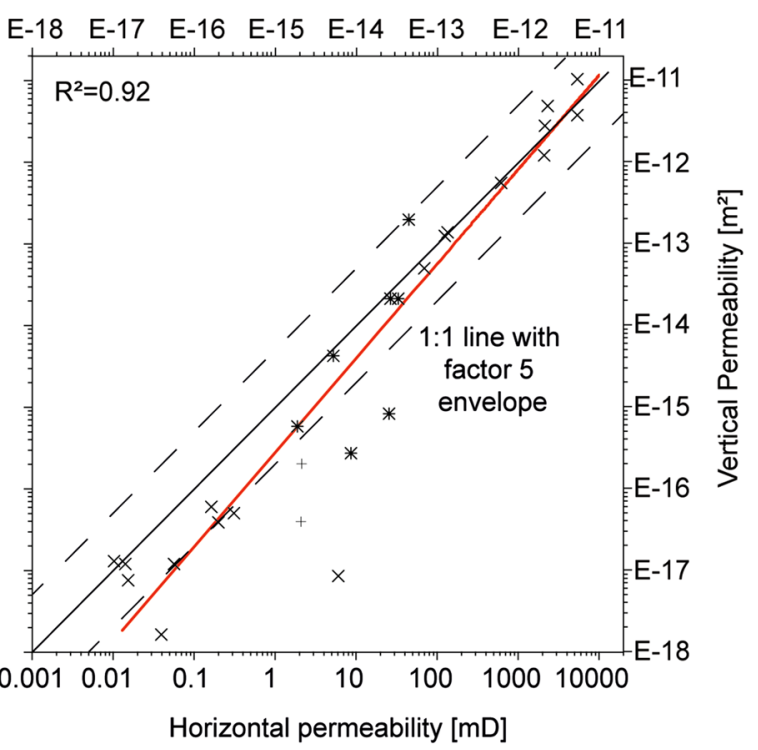

\ Quarry D $\triangleleft$ Quarry E $\triangleleft$ Quarry F
+ Sheet sands
Fig. 10 Klinkenberg-corrected permeability measured on plugs drilled parallel to bedding (abscissa) versus the corresponding plugs drilled normal to bedding (ordinate). Both axis are plotted in logarithmic scale. The red line shows a logarithmic correlation $\left(R^{2}=0.92\right)$.

The black line is a 1:1 line encompassed by a dotted factor 5 and divi-

correlations within the individual populations of Cornberg, Flechtingen or Penrith Sandstones (Fig. 111).

\section{Discussion}

\section{Paragenesis}

\section{Early diagenesis}

Mechanical compaction Mechanical compaction commenced after initial deposition due to burial. Due to ongoing consolidation, both by compaction and cementation, the effect on porosity reduction by mechanical compaction in clean sandstones typically begins to approach equilibrium at burial depths exceeding $2 \mathrm{~km}$ (Paxton et al. 2002).

Clay mineral and iron oxide grain coatings Tangential clay mineral or iron oxide grain coatings have been encountered in all three study areas (Fig. 6a, f, i, j), encompassing detrital grains and present at grain contacts, thus predating any other authigenic mineral. Pigmented and continuous iron oxides coatings (Fig. 6i) are interpreted to be formed by sediment redding, sourced by weathering of iron-bearing sor 5 envelope of the 1:1 line, demonstrating larger permeability differences from horizontal to vertical measurements in less permeable samples. Quarries: A-Cornberg, B and C-Flechtingen, D to $\mathrm{F}-$ Penrith

minerals e.g. biotite and hornblende (Walker and Honea 1969). Grain coatings are a well-described occurrence in arid fluvio-eolian depositional environments (Esch et al. 2008; van Houten 1973), and have been previously related to be formed by clay infiltration (Matlack et al. 1989; Molenaar and Felder 2018), as well as surface and soil formation processes (Walker and Honea 1969). Grain coatings are apparently not linked to the depositional environment in arid continental systems (Busch 2020; Busch et al. 2020), while the distribution of grain coatings can be correlated to depositional environments in modern estuarine sediments (Woolridge et al. 2017). Grain coatings are shown as inferred smectite coatings in Fig. 12, which serve as precursors for tangential illite coatings in arid Rotliegend sandstone systems (Molenaar and Felder 2018). The varying distribution of clay mineral grain coatings in Penrith Sandstones could be caused by clay abrasion caused by grain migration (Ajdukiewicz et al. 2010), where only the smaller grains were able to retain their clay coats, which would be in agreement with our observation, showing preserved clay coatings primarily on smaller grains (Fig. 6j). A further potential control on grain coatings might be the climate due to an increasing/decreasing amounts of humidity (Mader and Yardley 1985). 

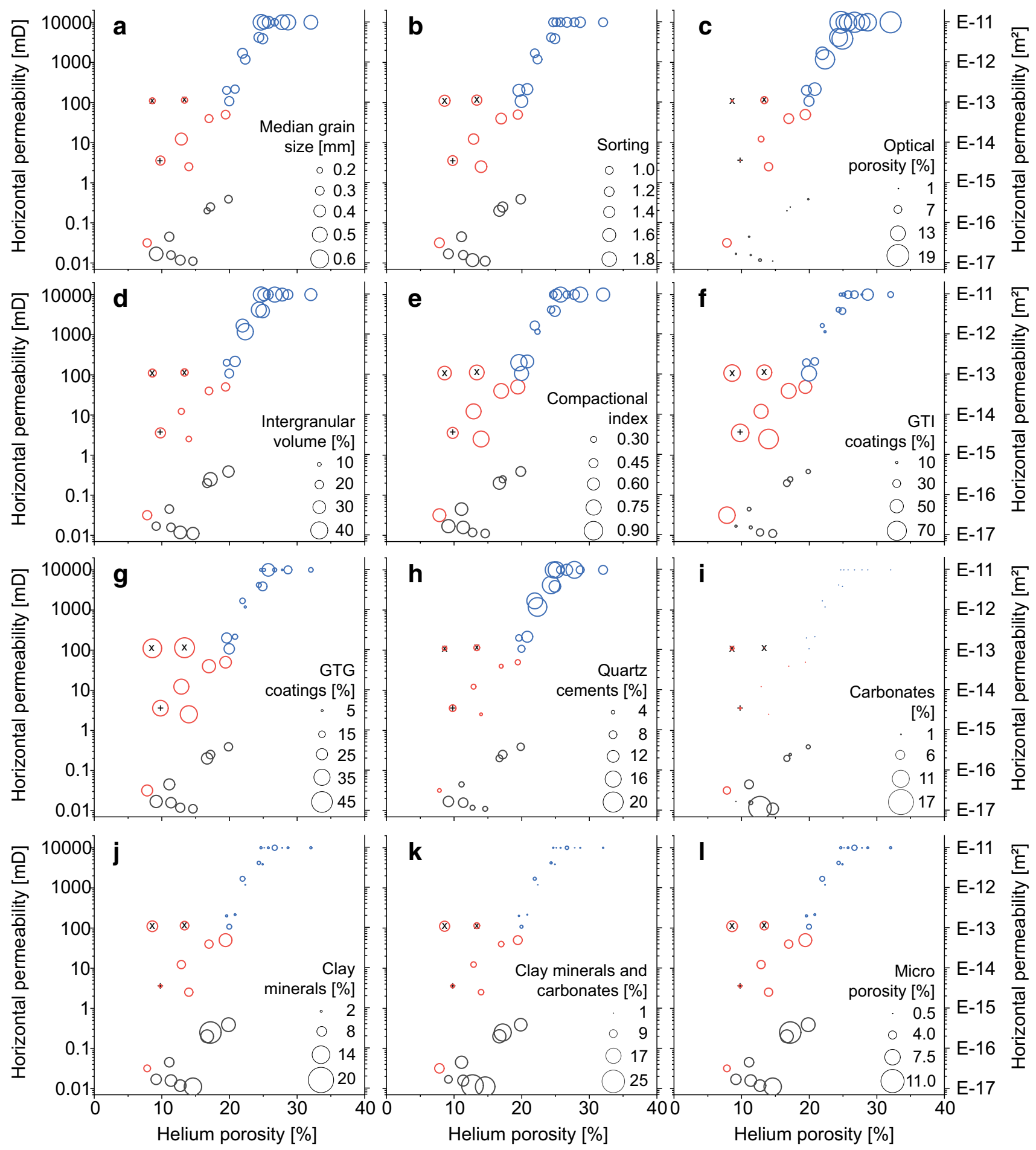

Cornberg Sandstones Flechtingen Sandstones Penrith Sandstones

Fig. 11 Matrix-scatter plotter with helium porosity on the abscissa and horizontal permeability on the ordinate in log-scale. Each diagram is labeled a to $\mathbf{l}$ in its upper left corner. Bubble sizes indicate a variable specific to the respective diagram in relation to the porosity and permeability. The variable is given with scale bar in the lower right of the respective diagram. Color coding refers to the three study areas. Three specific Flechtingen Sandstone specimen were indicated with an $\mathrm{x}$ (dune) or + (sheet sands), while fluvial Flechtingen Sandstones have not been marked. GTG grain-to-grain, GTI grain-to-IGV, $I G V$ intergranular volume 
Feldspar dissolution As feldspars are not stable under $\mathrm{pH}$ conditions encountered in meteoric waters (Lanson et al. 2002; Yuan et al. 2015), dissolution processes leading to the formation of intragranular feldspar porosity (Fig. 5b) may have started pre-deposition already, and likely commenced throughout early diagenesis until the influence of meteoric waters seized during burial diagenesis.
Kaolinite As kaolinite was illitized in some samples from Cornberg and Penrith Sandstones (Fig. 6c) it must have formed prior to illitization in these samples, likely during early diagenesis as described also by Becker et al. (2017). Early diagenetic processes include the dissolution of feldspar and subsequent formation of kaolinite (Ketzer et al. 2003; Lanson et al. 2002) in the presence of undersaturated meteoric waters (Lanson et al. 2002). Kaolinite formed dur-

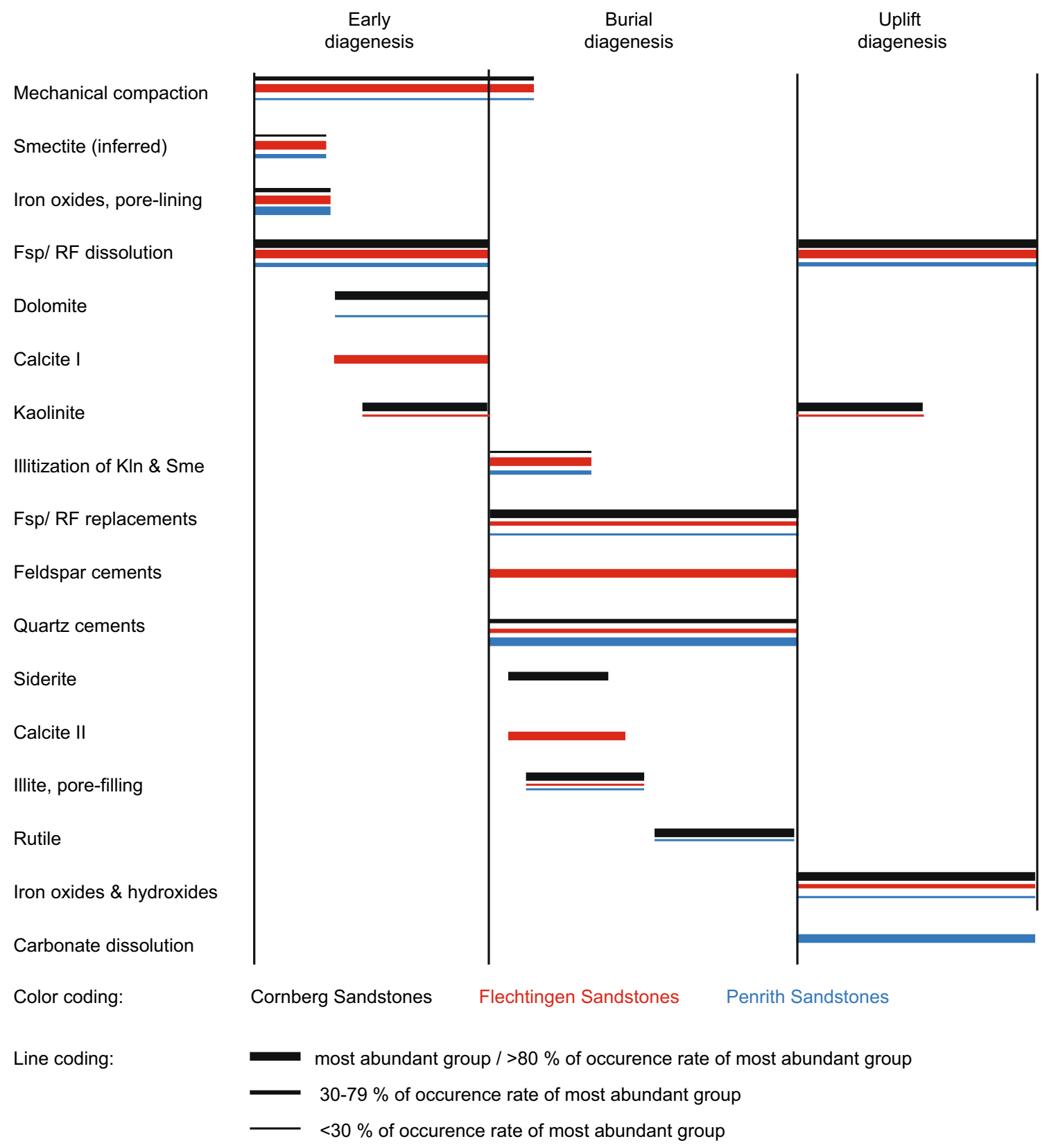

Fig. 12 Paragenetic sequence determined from textural and spatial relations of authigenic minerals. The left line is giving the respective diagenetic alteration sorted by relative first occurrence. Diagenetic alterations are subsequently interpreted to have been formed during early, burial, and/or uplift diagenesis. Color coding relates to the three study areas. Line thickness coding relates to the abundance of the respective diagenetic alterations based on the average petrographic parameter for the study area (data in supplementary material). Fs $p$ Feldspar, $R F$ rock fragment, $K \ln$ kaolinite, Sme smectite 
ing early diagenesis is replaced during subsequent burial by kaolinite/dickite assemblages and can form illite in geochemically open system if a $\mathrm{K}^{+}$source is available (Berger et al. 1997; Lanson et al. 2002).

Carbonate cements Calcite cements in Flechtingen Sandstones are showing poikilotopic textures encasing grains with floating to point grain contacts (Fig. $6 \mathrm{f}$ ), indicating early diagenetic cementation prior to significant mechanical compaction (Morad 1998; Walderhaug 1990), likely formed during an evaporative stage typical for arid fluvio-eolian systems (Morad 1998). Similar poikilotopic textures of dolomite with floating to point grain contacts can be observed in Cornberg Sandstones (Fig. 6b) and may be related to marine ingressions (Morad 1998; Vincent et al. 2018), for instance the Zechstein Sea ingression in the late Permian (Legler and Schneider 2008; Stollhofen et al. 2008).

\section{Burial diagenesis}

Illitization of clays and feldspars, and feldspar replacements As illitic grain coatings are present at grain contacts, they or a precursor mineral phase must have been present prior to mechanical compaction. The recrystallization of tangential illite was also inferred from K/Ar dating of illite in other Rotliegend deposits (Liewig and Clauer 2000) supporting the burial diagenetic recrystallization or replacement of a precursor clay mineral grain coating. For other Rotliegend deposits in northern Germany, Busch et al. (2020) derived a smectitic-chloritic clay mineral grain coating phase, interpreted to form via the recrystallization of a smectitic precursor phase. However, illitic and illite/ smectite mixed-layer clays as grain coatings have also been reported as a detrital to eo-diagenetic component in active eolian depositional systems (Busch 2020).

Two phases of feldspar cements were observed in Flechtingen Sandstones; a potassium feldspar cement (Fsp I) encompassing detrital feldspar grains, and an albite cement (Fsp II) encompassing Fsp I (Fig. 6g). Albite was also observed to partially replace detrital feldspars (Fig. 6g) in Flechtingen Sandstones. Additionally, feldspars were replaced by illite, which was encountered in all study areas (Fig. 6d). The two feldspar overgrowth generations are in agreement with the results of Fischer et al. (2012). Also considering feldspar cement ages in Flechtingen Sandstones determined by earlier studies (Fischer et al. 2012) as well as textural relations (Fig. 6g), we interpret feldspar cementation to be related to burial diagenetic processes pre to syn-dating quartz cementation.

Illite was observed to replace early diagenetic kaolinite in minor quantities (Fig. 6c) in Cornberg Sandstones. Partial illitization of kaolinite has been reported in previous studies on sample origination from below the Kupferschiefer and elsewhere (Becker et al. 2017; Ehrenberg and Nadeau 1989; Lanson et al. 2002). A limited source of $\mathrm{K}^{+}$driving the reaction to form illite from kaolinite constrained by reaction kinetics and the $\mathrm{K}^{+} / \mathrm{H}$ ratio was identified as a control on illitization in previous studies (Huang et al. 1993). Based on the kinetic constraints illustrated by Lander and Bonnell (2010), we interpret the partial illitization of early diagenetic kaolinite to be due to a limited $\mathrm{K}^{+}$supply. Previous studies on the timing of illite replacements and cements in the Northern German Basin suggest a wide time-range from 210 to $140 \mathrm{Ma}$ (Liewig and Clauer 2000; Ziegler 2006; Zwingmann et al. 1998), however, they all relate feldspar overgrowths and illitization to burial diagenetic processes (Ziegler 2006). A paragenetic interpretation of feldspar cements based on textural relations only is not straightforward due to small volumes of feldspar cements. Based on textural evidence, Fsp II must have formed after Fsp I, and also in temperature settings likely exceeding $145^{\circ} \mathrm{C}$ based on the dissolution kinetics of feldspars compared to albite growth rates (Aagaard et al. 1990). Illite in parts of the Northern German Basin was interpreted to be associated with Carboniferous fluids, driving feldspar dissolution and subsequent illitization (Gaupp et al. 1993). Two major phases of illites were reported in the Northern German Basin and Dutch Basin dated to 200-180 Ma and around $90 \mathrm{Ma}$ (Gaupp et al. 1993; Gaupp and Okkerman 2011), which coincide with the opening of the Atlantic ocean and the Late Cretaceous basin inversion (Kley and Voigt 2008; Ziegler 1990). The tectonic activity was interpreted to have enabled the reactivation of old Permo-Carboniferous fault systems, on which acidic fluids were able to circulate (Gaupp et al. 1993). We interpret feldspar cementation and replacements as well as illitization of kaolinite to be possible throughout the entire burial diagenesis, however likely prevalent in an early phase (Fsp I) and a later phase (Fsp II) (Fig. 12), which could be linked to increased fluid migration during Early Jurassic Atlantic opening.

Quartz cements The formation of quartz cements generally requires temperature exceeding $75-80^{\circ} \mathrm{C}$ (Walderhaug 1994). Assuming a geothermal gradient of $35^{\circ} \mathrm{C} / \mathrm{km}$, this would result in minimum burial depths of $2 \mathrm{~km}$. Possible early diagenetic silica cement may have formed in an arid depositional system (Folk and Pittman 1971) and has been interpreted to be present as poikilotopic textures in Flechtingen Sandstone samples by Fischer et al. (2012). However, these poikilotopic quartz cements are frequently observed to encase both phases of feldspar cement (Fig. 6g), which in turn are related to burial diagenesis. Thus, a burial diagenetic origin of quartz cements based on textural relations is favored. Although it contradicts other interpretations in the same study area (Fischer et al. 2012; Heidsiek et al. 2020), 
it is in accordance with observed petrographic textures from different outcrops (Figs. 1c, 6g).

Early diagenetic chalcedony cementation was proposed by (Waugh 1970b) for Penrith sandstone samples. In their model, siliceous dust was remobilized by highly alkaline evaporitic groundwaters and finally recrystallized to quartz during burial diagenesis. However, cathodoluminescence studies show at least two discrete growth events and no petrographic evidence for recrystallization, implying the primary origin of the quartz cements (Turner et al. 1995). Furthermore, fluid-inclusion data suggest a precipitation temperature of at least $95^{\circ} \mathrm{C}$ for quartz cements in Penrith Sandstones (Turner et al. 1995). Quartz cementation is dependent on silica availability, which can be sourced by the autochthonous illitization of smectite (Lanson et al. 2002), from dissolution seams (Walderhaug and Bjørkum 2003) or allochthonous hydrothermal fluid circulation (Gaupp et al. 1993) during burial. Silica in Cornberg Sandstones is interpreted to be mainly sourced by the autochthonous illitization of smectite (Lanson et al. 2002) due to the large amount of illite and feldspars replacements (Fig. 6 a, c-d). The silica origin of the Northern German Basin Rotliegend and potentially also Flechtingen Sandstones might be related to hydrothermal fluid circulation (Gaupp et al. 1993) in addition to autochthonous processes.

Due to the small abundance of feldspars in Penrith Sandstones, an allochthonous source for silica for the abundant quartz cements is implied. Turner et al. (1995) discussed the underlying Carboniferous shales to be a minor contributor via pressure dissolution of silt-sized quartz in mudstones (Milliken 1992). Quartz cementation is more easily facilitated on a quartz grain or rock fragment containing quartz, as a result reduced substrate areas by clay coatings result in a reduced abundance of quartz cements (Ajdukiewicz and Larese 2012; Busch et al. 2017; Monsees et al. 2020a; Pittman et al. 1992). Grain sizes and mono- or polycrystallinity of quartz substrates also affect overgrowth cement volumes (Lander et al. 2008; Waugh 1970a). Smaller volumes of syntaxial overgrowth cements are formed on smaller grains as opposed to coarser grains, when subject to the same conditions during diagenesis (Lander et al. 2008; Prajapati et al. 2018). Monocrystalline grains form larger volumes of syntaxial quartz cement as opposed to polycrystalline grains of the same size when subject to the same conditions during burial (Lander et al. 2008; Prajapati et al. 2020). Growth rates of quartz cements are also increasing with grain size (Lander et al. 2008; Walderhaug et al. 2000), and are significantly higher prior to reaching euhedral shape, and significantly lower after the euhedral shape was reached (Lander et al. 2008; Prajapati et al. 2020). This is reflected by Penrith Sandstone samples showing the largest volumes of quartz cements and lowest GTI coating coverages, while Cornberg and Flechtingen Sandstones show smaller quartz cement volumes (Fig. 8b). However, illite GTI coatings in Cornberg Sandstones are almost as low as in Penrith Sandstones.

Additionally, the occurrence and preservation of early diagenetic carbonates in Cornberg Sandstones is interpreted to have reduced the reactive surface area of quartz grains, resulting in a smaller substrate area. The smaller grain sizes in Flechtingen and Cornberg Sandstones, therefore, are interpreted to be an additional controlling factor resulting in smaller quartz cement abundances. As a result, silica provided by the illitization of feldspar, smectite and kaolinite (McKinley et al. 1999), potentially enhanced by hydrothermal fluids enriched in silica (Gaupp et al. 1993) in conjunction with silica mobilized by quartz dissolution during chemical compaction (Kristiansen et al. 2011), are interpreted to be responsible for in-situ formation of quartz cements throughout burial diagenesis (Fig. 12).

Carbonate cements As siderites in Cornberg Sandstones are partly overgrowing quartz cements (Fig. 6a, b), they are interpreted to be syn- to postdating quartz precipitation (Fig. 12). Similarly, the rare second calcite phase in Flechtingen Sandstones was observed to overgrow both quartz and feldspar cements (Fig. 6h) and is therefore interpreted to postdate quartz and feldspar cementation (Fig. 12). Quartz solubility increases under alkaline conditions (Knauss and Wolery 1988), while carbonate solubility generally increases under acidic conditions (Morad 1998). The contemporaneous formation of quartz and siderite would be geochemically plausible under relatively neutral $\mathrm{pH}$ systems. Burial diagenetic siderite in the Dutch part of the Southern Permian Basin has been discussed to be linked to a shift in fluid chemistry to a predominately alkaline $\mathrm{pH}$ during JurassicCretaceous uplift (Gaupp and Okkerman 2011).

Pore-filling illite Due to the overgrowth of pore-filling illite on siderite and all previously discussed cement phases in Cornberg Sandstones, they are interpreted to have formed after the burial diagenetic siderites in Cornberg Sandstones, respectively quartz cements in Flechtingen and Penrith Sandstones (Fig. 12). The formation of illite is generally favored in acidic pH conditions (Gaupp et al. 1993; Gaupp and Okkerman 2011), and dependent on the process of formation, temperatures ranging from 70 to $140^{\circ} \mathrm{C}$ (Worden and Morad 2003). Pore-filing illite in Cornberg Sandstones being more abundant than in the other study areas is interpreted due to the close proximity to a fault zone (MotzkaNöring et al. 1987), which has been identified to be the main driver of pore-filling meshwork illite cementation in the Northern German Basin (Gaupp and Okkerman 2011). Based on the textural relationships in combination with the timing of pore-filling meshwork illite in the Northern German and Dutch Basin (Gaupp et al. 1993; Gaupp and Okkerman 2011), pore-filling illite is interpreted to have formed 
during burial diagenesis postdating the onset of quartz cementation, but predating the late Cretaceous inversion. Previous studies determined illite ages in Rotliegend sandstones with $\mathrm{K}-\mathrm{Ar}$ dating, demonstrating that illite formed between 180 and $210 \mathrm{Ma}$ in the German part of the Southern Permian Basin (Clauer et al. 2012; Liewig and Clauer 2000; Zwingmann et al. 1998). Illite ages become younger towards the Dutch and UK sector with ages ranges from 100 to $190 \mathrm{Ma}$ (Clauer et al. 2012). Textural observations suggest that diagenetic rutiles postdate pore-filling illites and kaolinites in Cornberg Sandstone (Fig. 6c), supporting the episodic growth of illite during burial diagenesis (Fig. 12). Therefore, we interpret illite growth to be episodic in the early Jurassic as proposed in previous studies, likely related to a hyperthermal plate tectonic event, e. g. the opening of the Atlantic ocean (Liewig and Clauer 2000; Zwingmann et al. 1999).

Chemical compaction Long grain contacts between quartz grains encasing illitic grain coatings form quartz-illitequartz interfaces, which enhance chemical compaction by electrochemical potential differences (Greene et al. 2009; Kristiansen et al. 2011). Therefore, intense chemical compaction should require mostly continuous illite GTG coatings, as well as an absence of major pore-filling early diagenetic cements, which would inhibit the development of long, concavo-convex or sutured grain-to-grain contacts. Chemical compaction appears to correlate with GTG coatings, where higher grain coating coverages coincide with smaller IGVs in this study (Fig. 8b), which is in agreement with Monsees et al. (2020a). Previously the amount of pressure dissolution was related to the total amount of clay in the sandstones (Tada and Siever 1989), but these results in conjunction with previous results from Monsees et al. (2020a) highlight that the local abundance of illitic clay minerals at grain contacts may aid in extending such a model. Flechtingen Sandstones lacking major pore-filling cements, showing the most continuous illite coatings, and lowest IGVs, therefore, are interpreted to have experienced the highest degree of chemical compaction. Mechanical compaction in clean sands like Cornberg and Penrith Sandstones did not reduce IGVs below the theoretical minimum of 26\% (Paxton et al. 2002), however, IGVs in Flechtingen Sandstones are reduced down to $15 \%$. Considering burial histories for study areas where they are available (Kohlhepp 2012; Turner et al. 1995), burial depths are interpreted to be sufficient to lead to a maximum mechanical compaction under the boundary conditions proposed by Paxton et al. (2002). Chemical compaction has been discussed to be mainly controlled by thermal boundary conditions in burial depths exceeding 2 to $3 \mathrm{~km}$, and only to a lesser extent by effective stresses (Bjørlykke 2006). Large IGV reductions therefore might not require extreme burial, but can also be observed in the same well, only several meters apart (Monsees et al. 2020a). This is interpreted to be due to a combination of chemical compaction as shown by partly sutured grain contacts (Fig. 5b, c), and the poorest average sorting (supplementary material). The presented correlation of illitic GTG grain coating coverages and IGV (Fig. 8b) also implies that the variability of burial scenarios, i.e. variability in effective vertical stresses, does not appear to be the main control on the process of chemical compaction. Consequently, intense early diagenetic dolomite cementation in Cornberg Sandstones and intense quartz cementation in Penrith Sandstones not inhibited by intense clay coatings are interpreted to mitigate major effects of chemical compaction in these study areas.

\section{Uplift diagenesis}

Kaolinite and feldspar dissolution Kaolinite was observed to overgrow quartz cements in Cornberg Sandstones (Fig. 6c), thus postdating quartz cements formed during burial diagenesis. Kaolinite however is typically formed during early diagenesis, favoring lower temperatures and meteoric waters compared to its burial diagenetic products dickite, illite and chlorite (Lanson et al. 2002; Worden and Morad 2003). However, textural evidence suggests only minor amounts of early diagenetic kaolinite, possibly due to very acidic fluids (Lanson et al. 2002). Possible $\mathrm{K}^{+}$sources during diagenesis are dissolving K-feldspars (Ehrenberg and Nadeau 1989). Early diagenetic kaolinite was subsequently partly illitized during burial diagenesis (Lanson et al. 2002). Early diagenetic carbonates are preserved (Fig. 6 b), suggesting a limited exposure to very acidic fluids. Therefore, kaolinite in Cornberg Sandstones is interpreted to have formed during early diagenesis and uplift diagenesis (Fig. 11) under the influence of meteoric waters and below earliest illitization temperatures of $60^{\circ} \mathrm{C}$ (Lanson et al. 2002; Worden and Morad 2003). A later phase of feldspar dissolution is interpreted to have occurred during uplift and exposure at the surface due to interactions with meteoric waters.

Iron hydroxides Textural relations imply a formation of iron hydroxides in Cornberg Sandstones syn- to postdating uplift related kaolinite cement (Fig. 6c), as well as postdating quartz cement formation in Flechtingen and Penrith Sandstones. Detrital or early diagenetic goethite would have been altered to hematite under burial diagenetic conditions (Berner 1969), therefore it is more plausible for iron hydroxides to have been transported under oxic conditions along with fractures, also explaining observed Liesegang rings on outcrop scale (Chan et al. 2000). Due to textural relations of iron hydroxides with burial diagenetic minerals in all studied samples, iron hydroxides are interpreted to have formed during the latest stages of uplift diagenesis (Fig. 12) under the influence of humid conditions in the UK and Germany. 
Carbonate dissolution Carbonate dissolution in Penrith Sandstones is apparent by the rhombohedral secondary porosity engulfed by quartz cements (Fig. 6i), implying the dissolution process took place after quartz cementation. The occurrence of dolomite cements in Penrith Sandstone samples from the subsurface (Turner et al. 1995), in combination with the solubility of carbonate minerals by meteoric waters (Morad 1998) support the theory of dolomite dissolution during uplift diagenesis (Fig. 12). The significantly higher permeabilities in Penrith Sandstones are interpreted to have catalyzed carbonate dissolution additionally, while low permeability Cornberg Sandstones were able to retain significant carbonate cement volumes up to $15 \%$.

\section{Vertical permeability heterogeneity}

Results demonstrate a larger offset between horizontal $\left(k_{\mathrm{H}}\right)$ and vertical permeability $\left(k_{\mathrm{V}}\right)$ in less permeable sandstones (Fig. 10), which carries implication for permeability-related modelling approaches in sandstones. Industry practice assumes vertical (normal to bedding) permeabilities to be $10 \%$ of horizontal (parallel to bedding) permeabilities (Cannon 2018; Gibbons et al. 1993). Recent outcrop analog studies also demonstrated heterogeneity in lateral permeability in Triassic Buntsandstein of up to two orders of magnitude in a single bed several meters apart (Schmidt et al. 2020b). Upper Carboniferous sandstones also show lateral permeability variations by two orders of magnitude over $150 \mathrm{~m}$ lateral distance in a $3 \mathrm{~m}$ bed (Becker et al. 2019, 2017). However, it is commonly assumed to not vary significantly in the lateral direction in reservoir modelling approaches (Cannon 2018; Gibbons et al. 1993). Minimal reduction from $\mathrm{k}_{\mathrm{H}}$ to $\mathrm{k}_{\mathrm{V}}$ for sandstones exceeding permeabilities of $100 \mathrm{mD}$ is interpreted to be an effect of sample homogeneity, having no significantly less permeable laminae normal to bedding. This in agreement with previous experimental studies on homogenous sandstones over $100 \mathrm{mD}$ (Iheanacho et al. 2012; Meyer 2002). Micro-computer tomographybased permeability simulations of Penrith Sandstones also show insignificant variations from horizontal to vertical permeability from 1500 to $800 \mathrm{mD}$ (Monsees et al. 2020b). Sandstones with permeabilities below $10 \mathrm{mD}$ show larger permeability reduction from $\mathrm{k}_{\mathrm{H}}$ to $\mathrm{k}_{\mathrm{V}}$ (this study, Iheanacho et al. 2012), which are interpreted as a heterogeneity imposed by depositional environment, grain size and diagenetic alteration. There seems to be no direct control of the depositional environment on permeability in this data set (Fig. 10), rather the vertical permeability seems to be linked to horizontal permeability, which is mostly controlled by diagenetic alterations (this study, Becker et al. 2017; Busch et al. 2020). The depositional environment and grain size should be of larger importance in shallow and thus not heavily diagenetically overprinted settings, while diagenetically induced permeability reduction in sandstones will increase with burial depth (Paxton et al. 2002) and temperature exposure (Busch et al. 2018; Lander et al. 2008; Walderhaug et al. 2000). In summary, low permeability samples are either heavily compacted (Flechtingen Sandstones) or heavily cemented (Cornberg Sandstones, also forming planar dissolution seams due to chemical compaction), which may impede fluid flow and thus permeability (Fossen et al. 2011).

\section{Impact on reservoir quality}

\section{Depositional parameters}

The detrital composition is interpreted to have no effect on reservoir quality, as both Cornberg Sandstones and Penrith Sandstones show a predominantly mature, quartz-dominated detrital composition (Fig. 4), but significant permeability and porosity contrasts (Fig. 9a). The impact of depositional environments is not straightforward, as both the best and worst reservoir qualities were observed in eolian dunes, and intermediate reservoir qualities in fluvial sandstones (Fig. 9 b). Depositional systems are discussed to be one of the main or the main controlling factors on reservoir quality in literature (dos Anjos et al. 2000; Griffiths et al. 2019; Morad et al. 2010). It is further developed towards an integrated approach of depositional systems overprinted by diagenesis during burial (Becker et al. 2019; Busch et al. 2020; Ehrenberg 1990; Gaupp and Okkerman 2011; Taylor et al. 2010). This study comprises of fluvio-eolian sandstones only, consequently a population bias against a strong control depositional control due to the lack of depositional system variety is introduced into the data set. As opposed to Heidsiek et al. (2020) a facies dependent reservoir control on plug-scale reservoir quality analyses cannot be delineated in Flechtingen Sandstones, as is also supported by previous studies in similar arid or semi-arid fluvio-eolian deposits (Busch et al. 2019, 2020; Kunkel et al. 2018; Monsees et al. 2020a). The effect of grain size on permeability is also interpreted to be partly caused by a population bias, which is also discussed by Wadsworth et al. (2016). Larger grain size generally results in higher permeability (Shepherd 1989), which is also evident in Penrith Sandstones, however, no such distinctions can be made for Flechtingen and Cornberg Sandstones (Fig. 11a). Better sorting is discussed to have a positive effect on reservoir quality due to larger packing induced porosities (McKinley et al. 2011), however, no such effect can be observed in this data set (Fig. 11b). The lack of clear correlations of depositional parameters with reservoir quality is interpreted as significant diagenetic overprint superimposed on reservoir quality controlling parameters during deposition, particularly in Cornberg and Flechtingen Sandstones. Consequently, reservoir quality assessment should always include the analysis of diagenetic alteration. 


\section{Mechanical compaction and early diagenetic blocky cements}

Mechanical compaction generally is considered the most significant factor in porosity loss of clean sandstones during early and burial diagenesis due to the reduction of potential porosity (IGV) from approximately 45 to $26 \%$ (Lundegard 1992; Paxton et al. 2002). However, mechanical stresses alone do not explain observed IGVs of up to $40 \%$ in Penrith Sandstones, which have been buried to approximately $3 \mathrm{~km}$ depth (Turner et al. 1995), resulting in an expected IGV below 30\% (Paxton et al. 2002). Furthermore, high porosities and IGVs in hydrocarbon reservoirs also make a purely stress-dependent porosity reduction unlikely (Salem et al. 2000; Taylor et al. 2010). Outcrop analog studies on Lower Triassic Buntsandstein sandstones demonstrated differences in the porosity reduction process from mainly compactional to mainly cementational control over lateral distances of only several meters (Schmidt et al. 2020a, b). This IGV loss might be counteracted by grain-stabilizing early diagenetic cementation of carbonate minerals, anhydrite or halite (Ajdukiewicz et al. 2010; Mahmic et al. 2018), which are discussed to positively contribute to reservoir quality due to the possible dissolution and formation of secondary intergranular porosity during burial (Taylor et al. 2010; Worden et al. 2018). High IGVs and dissolved dolomite rhombs in Penrith Sandstones are interpreted to indicate an early diagenetic cement phase, however, the total amount of dissolved carbonates or other phases is unclear. The identified amounts of carbonate dissolution porosity in Penrith Sandstones encased in quartz overgrowths are too small to be of significant impact on overall permeability.

\section{Grain coatings and chemical compaction}

Grain coatings, quantified by the grain coating coverage, can inhibit quartz cementation (Fig. 8a) (Ajdukiewicz and Larese 2012; Esch et al. 2008), showing similar trends reported in previous works (Busch et al. 2017; Monsees et al. 2020a). Cornberg Sandstones show a different trend than Flechtingen and Penrith Sandstones due to early diagenetic carbonate precipitation, which is independent of grain coating coverage in siliciclastic sandstones (Ajdukiewicz et al. 2010; Esch et al. 2008). Early diagenetic carbonate cementation in Cornberg Sandstones is interpreted to have reduced the effective surface area of detrital quartz grains, leading to comparable amounts of quartz cement as Flechtingen Sandstones, although the grain coating coverage in Flechtingen Sandstones is much higher (Fig. 8a). The direct impact of GTI grain coatings on reservoir quality however remains indistinct (Fig. 11f).

Grain-to-grain (GTG) coatings deliver the same trend as originally described by Monsees et al. (2020a), showing smaller IGVs weakly correlating with larger GTG coatings due to catalyzed chemical compaction by electrochemical potential differences on quartz-illite-quartz interfaces (Greene et al. 2009; Kristiansen et al. 2011). The ambivalent effect of illite clay coatings potentially inhibiting quartz cementation but driving chemical compaction has led some authors to the conclusion, that contrary to chlorite coatings, illite coatings mostly have a deteriorating effect on reservoir quality (Gaupp and Okkerman 2011; Storvoll et al. 2002). Thus, a differentiation between GTI and GTG coatings is necessary to fully address the variable effect of illitic grain coatings on reservoir quality based on our results and recent studies (Busch et al. 2020; Monsees et al. 2020a). The effect of GTG coatings on chemical compaction is interpreted to be reduced by the early diagenetic blocky cements in Cornberg Sandstones but shows a trend in systems without early diagenetic blocky cements towards better reservoir quality with less GTG coverage (Fig. 11g).

\section{Clay minerals and microporosity}

An increased amount of clay minerals has been observed to coincide with a reduction in reservoir quality (Fig. 11j), which is the expected result (Ajdukiewicz et al. 2010; Worden et al. 2018). As microporosity was derived from the abundance of clay minerals, it consequently also shows a negative correlation with reservoir quality (Fig. 111). Permeability is driven by the interconnectivity of the larger pores (Klinkenberg 1941), therefore the increased amount of porosity due to microporosity should have a minor impact on overall permeability. If petrographically derived microporosities after Hurst and Nadeau (1995) are subtracted from the helium porosity, a better fit with permeability is generated (Fig. 13). This effective helium porosity $\left(\phi_{\mathrm{E}}\right)$ is interpreted as a closer representation of the well-connected pore volume, as the better fit suggests that microporosity in clays contributes only to a minor degree to overall permeability in the studied sample set. Effective helium porosity shows a positive correlation of $R^{2}=0.93$ with helium porosity, which is closer to a 1:1 fit in more porous samples (Fig. 13a). This is interpreted as the higher offset between $\phi$ and $\phi_{\mathrm{E}}$ due to the increased abundance of clay minerals in the less porous samples. The derived scatter plot between permeability and $\phi_{\mathrm{E}}$ (Fig. 13b) shows an improved correlation coefficient of $R^{2}=0.78$ compared to regular helium porosity (Fig. 9a). Excluding the dune facies from Flechtingen Sandstones, which clearly show a different porosity-permeability relationship seemingly independent of porosity variation from all other data points (Fig. 13b) would result in an even better correlation coefficient of $R=0.91$. Overall, clay minerals are interpreted to be one of the main controls on a deterioration of reservoir quality, as they might retain porosity in form of microporosity but contribute to a loss of effective porosity, 
resulting in reduced permeabilities, which is in line with the results of previous studies (Becker et al. 2019; Ehrenberg 1990; Gaupp and Okkerman 2011).

\section{Burial diagenetic blocky and clay mineral cementation}

Quartz cement volumes show a positive correlation with permeability (Fig. 11h), although in fact the opposite would be expected (Ajdukiewicz et al. 2010; Becker et al. 2019; Busch et al. 2018; Ehrenberg 1990; Gaupp and Okkerman 2011). Because quartz cements are most abundant in Penrith Sandstones, other preserved cements are lacking (Fig. 6i, j), and have been compacted the least amount (Fig. 7). The large quartz cement volumes and IGVs imply a stabilization effect on the grain framework commonly observed for early diagenetic carbonates (Paxton et al. 2002). As a result, quartz cementation in Penrith Sandstones is interpreted to have a positive effect on reservoir quality by framework stabilization and inhibiting further compaction.

An increased amount of carbonate and clay minerals was also observed to be an important factor in reservoir quality deterioration in Cornberg and Flechtingen Sandstones (Fig. 11i, j). Considered individually, the effect on reservoir quality does not result in a good correlation (Fig. 11i, j), however previous studies in Triassic red bed sandstones reported a combined control of carbonates and clay minerals on reservoir quality (Schmid et al. 2004), which can also be observed here (Fig. 11 k). Pore-filling burial diagenetic illite cementation has been discussed as a reservoir quality deterioration factor in Northern German and Dutch
Rotliegend reservoir rocks, showing a significant reduction in permeability (Gaupp et al. 1993; Gaupp and Okkerman 2011) while retaining porosity (Hurst and Nadeau 1995). Pore-filling illites are interpreted to be a significant factor in reservoir quality deterioration based on their highest abundance in barely permeable Cornberg Sandstones.

\section{Uplift diagenesis}

Diagenetic alterations attributed to uplift diagenesis are interpreted to be of minor importance to reservoir quality due to the small volumetric abundance of iron hydroxides and kaolinites, which is largest in Cornberg Sandstones with around 3\%, and much lower in Flechtingen and Penrith Sandstones. Secondary porosity caused by carbonate dissolution in Penrith Sandstones (avg.: 0.1\%) is also negligible compared to their total porosity (avg. $\phi: 25.9 \%$ ). The uplift diagenetic dissolution of other pore-filling mineral phases can only be speculated since characteristic dissolution molds as in Penrith Sandstones are absent. Meanwhile, the uplift diagenetic dissolution of feldspars and rock fragments contributing to up to $40 \%$ of the total optical porosity in Flechtingen Sandstones and up to 25\% in Cornberg Sandstones represent a major part of optical porosity. Feldspars are chemically unstable under meteoric waters (Aagaard et al. 1990; Yuan et al. 2015). While microporosity in feldspar is considered a negligible contribution to permeability (Walker et al. 1995), intense formation of secondary porosity has been discussed to decrease overall reservoir quality if coinciding with pore-filling clay mineral cementation

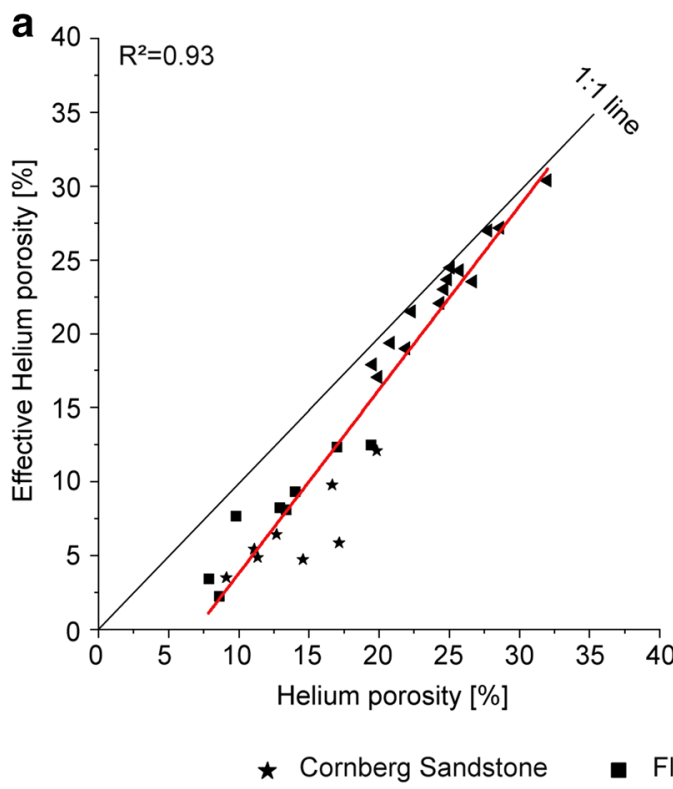

$\star$ Cornberg Sandstone b

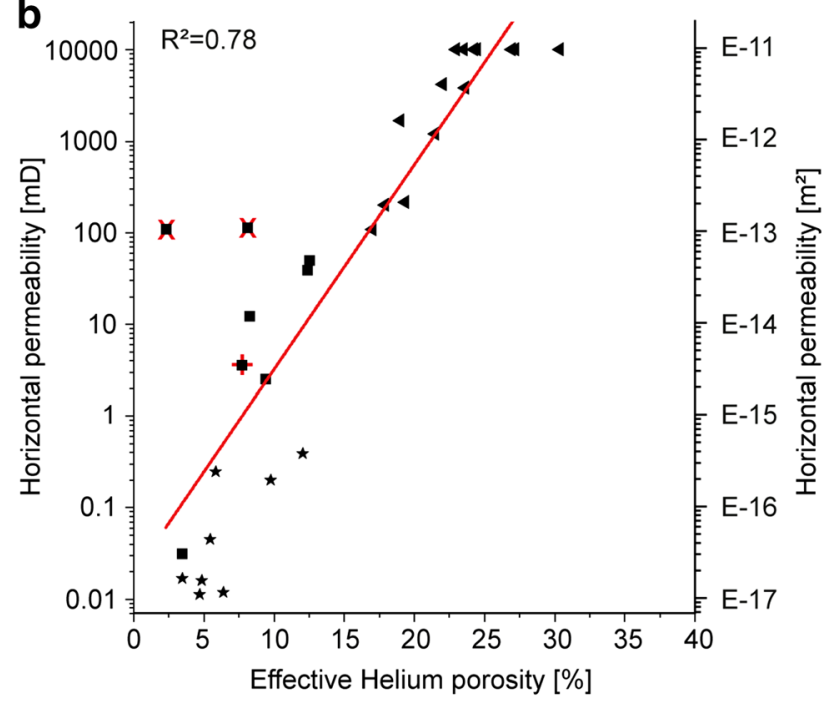

Flechtingen Sandstone
Penrith Sandstone
Fig. 13 a Scatter plot of porosity (abscissa) against effective porosity (ordinate) with a linear line of best fit (red) and 1:1 line (black). b Effective Helium porosity (abscissa) against horizontal permeability (ordinate) with linear line of best fit (red). Facies outliers in Flechtingen Sandstones are indicated by red $\mathrm{x}$ (dunes) and + (sheet sands) symbols 
(Ehrenberg 1990). Mahmic et al. (2018) interpret feldspar dissolution to contribute positively to reservoir quality if the dissolved grains are connected to intergranular porosity, thus contributing to the effective porosity. This is in agreement with Flechtingen Sandstones showing higher permeability than Cornberg Sandstones, but comparable porosity. Feldspar dissolution coinciding with intense pore-filling clay mineral cementation (Fig. 6c) in Cornberg Sandstones is interpreted to represent a case as described by Ehrenberg (1990), resulting in a negative impact on reservoir quality. In contrast, secondary porosity in Flechtingen Sandstones is commonly connected to the intergranular porosity (Fig. 5b). In combination with overall higher intergranular porosity in Flechtingen Sandstones, feldspar dissolution is interpreted to positively contribute to reservoir quality in Flechtingen Sandstones.

\section{Reservoir quality controls}

The reservoir quality controls have been compiled to a schematic diagram illustrating reservoir quality development during diagenesis (Fig. 14). The studied sandstones were deposited as unconsolidated sands with different compositions, which affects their compactive behavior and diagenesis. Early diagenetic carbonate cementation in Cornberg Sandstones reduced compaction and is interpreted to have partly inhibited quartz cementation by encompassing detrital quartz grains (Fig. 14).

During burial diagenesis, intense illitic grain coatings in conjunction with the largest amounts of ductile rock fragments led to highest compaction in Flechtingen Sandstones, while their absence led to the lowest compaction in Penrith Sandstones (Fig. 14). Reservoir quality was reduced by porefilling quartz, illite and siderite cements (Fig. 14). Due to the large intergranular volumes in Penrith Sandstones, intense quartz cementation is interpreted to have improved reservoir quality due to the prevention of further compaction. Reservoir quality in Flechtingen Sandstones was primarily reduced by chemical compaction, while reservoir quality in Cornberg Sandstones was reduced by intense cementation of illite, quartz and carbonates during early and burial diagenesis (Fig. 14). Published burial scenarios show peak subsidence of $3.4 \mathrm{~km}$ (Penrith, (Turner et al. 1995)), and varies between modeled 5-6 km (Flechtingen, Bebertal outcrop (Fischer et al. 2012)) and $2.5 \mathrm{~km}$ (well Peckensen $780 \mathrm{~km}$ NNE of Bebertal outcrop (Kohlhepp 2012)). As chemical compaction is mostly dependent on temperature and only to a lesser extent on effective stresses (Bjørlykke 2006), lower maximum temperatures are interpreted to have favored a preservation of porosity in Penrith Sandstones. This is also reflected by the lowest IGVs in Flechtingen Sandstones at Bebertal and highest IGVs in Penrith Sandstones (Fig. 11d). While no thermal data for Cornberg Sandstones is available, the intermediate IGVs in Cornberg Sandstones still match with modeled peak subsidence of $5 \mathrm{~km}$ further north (Schwarzer and Littke 2007) due to the preserved early diagenetic cementation inhibiting further mechanical compaction.

Uplift is interpreted to have had only a minor improving impact on reservoir quality as the volume of dissolved dolomite rhombs is negligible compared to the intergranular porosity in Penrith Sandstones (Fig. 14). Uplift-related feldspar dissolution is interpreted to positively contribute to reservoir quality due to the lack of pore-filling clay minerals in Flechtingen Sandstones but negatively contribute to reservoir quality in Cornberg Sandstones because of additional kaolinite precipitation (Fig. 14). No clear indicators for carbonate dissolution in Cornberg Sandstones were identified, and reservoir quality was deteriorated even more by the formation of pore-filling iron hydroxides (Fig. 14). These diagenetic controls are interpreted to have resulted in poor reservoir quality in Cornberg Sandstones with intermediate porosity and low permeability, intermediate reservoir quality with intermediate porosity and permeability in Flechtingen Sandstones, and large porosity and high permeability in Penrith Sandstones (Fig. 14). Nevertheless, plug-based reservoir quality analyses do not consider fractures, which are necessary for upscaling of reservoir properties (Busch et al. 2019; Kushnir et al. 2018).

\section{Conclusions}

Compaction is mechanical during early diagenesis and includes chemical compaction during burial diagenesis being highest in Flechtingen Sandstones. Several phases of pore-filling cementation were identified: quartz, feldspar, dolomite, calcite, siderite, illite, kaolinite and iron hydroxides. While early carbonate cementation is most intense in Cornberg Sandstones, cements in highly compacted Flechtingen Sandstone were mostly formed during burial diagenesis. Uplift resulted only in minor amounts of cementation and secondary porosity development by dissolution.

Grain-to-grain (GTG) clay mineral grain coatings show an enhancing effect on chemical compaction in all studied settings. Differences in the degree of compaction can be related to the relative timing of framework stabilization by early blocky cementation, and by the continuity of GTGcoating processes, highlighting the necessity for detailed diagenetic studies in reservoir quality assessments.

Depositional parameters such as depositional environments, grain size and sorting are shown not to be the main governing factors for reservoir quality in the studied fluvioeolian Permian Rotliegend sandstones. Reservoir quality is interpreted to mainly depend on a combination of initial composition, early diagenetic framework stabilizing 


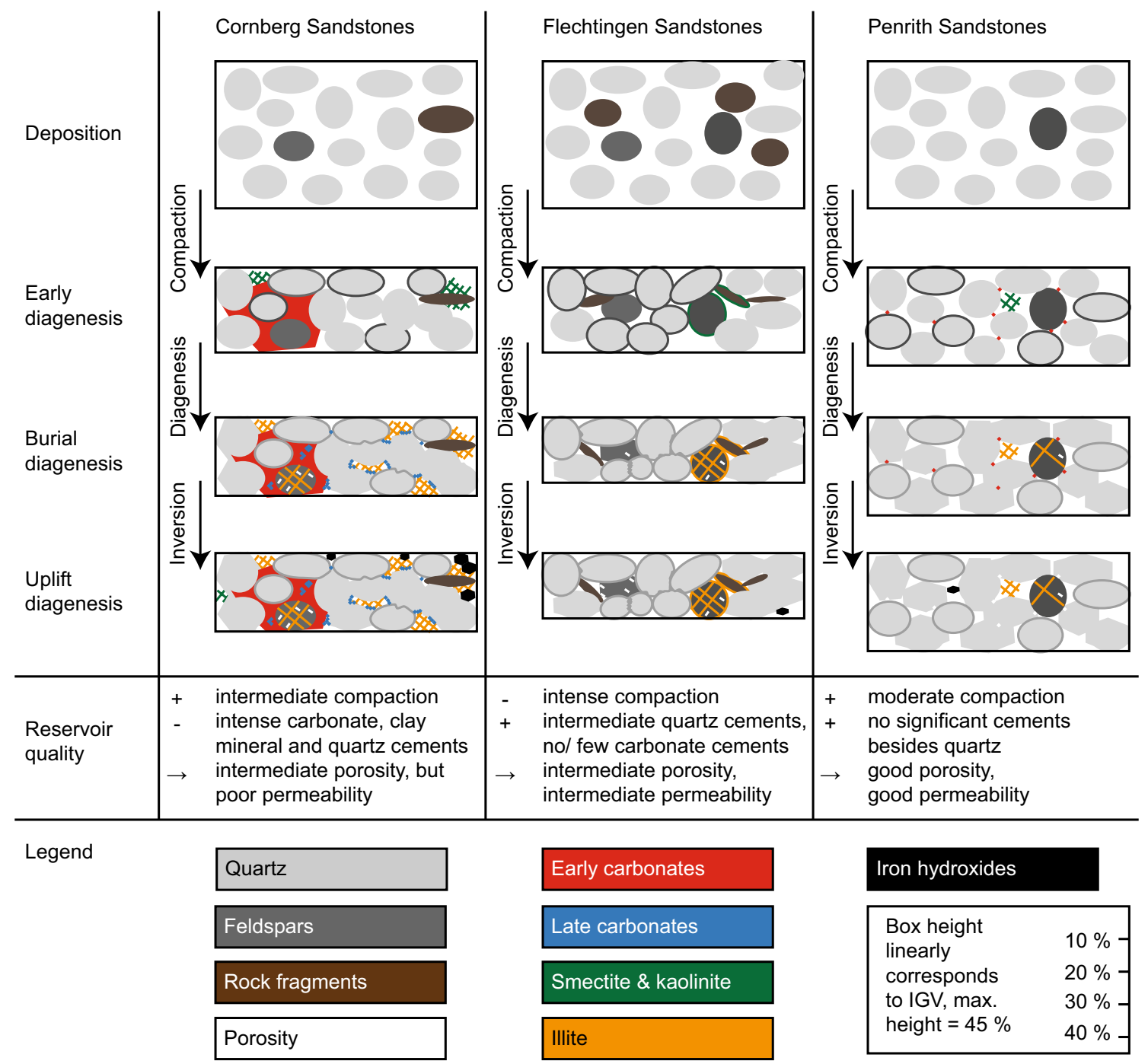

Fig. 14 Schematic illustration showing the process of reservoir quality reduction for Cornberg Sandstones, Flechtingen Sandstones and Penrith Sandstones during deposition, early diagenesis, burial diagen-

cementation, illitic GTI grain coatings which prevent quartz cementation, illitic GTG coatings which enhance chemical compaction, and burial diagenetic porosity-reducing cementation.

Poorest reservoir quality (avg. horizontal permeability: $0.96 \mathrm{mD}$ ) was encountered in Cornberg Sandstones linked to intense cementation (avg. cement volume: $24.9 \%$ ) and intermediate compaction (avg. intergranular volume: $26.4 \%$ ). Intermediate reservoir quality (avg. horizontal permeability: $34.9 \mathrm{mD}$ ) in Flechtingen Sandstones is controlled by intense mechanical and chemical compaction (avg. intergranular volume: $19.6 \%$ ) in conjunction with intermediate cementation (avg. cement volume: 16.7\%). Penrith Sandstones showed best reservoir quality (avg. horizontal permeability: $5906 \mathrm{mD}$ ) due to the lowest compaction (avg. intergranular volume: $30.0 \%$ ) supported by framework-stabilizing esis, and uplift diagenesis. Depositional compositions, IGVs, authigenic mineral volumes and porosity correspond to typical samples. $I G V$ intergranular volume

quartz cements (avg. cement volume: $16.4 \%$ ), resulting in a large and well-connected pore system with high permeability. These contrasts in reservoir quality are interpreted to be the result of diagenesis, which is controlled by the combined effect of depositional composition, fluid flow, burial history and thermal exposure.

The ratio between vertical (normal to bedding) and horizontal (parallel to bedding) permeability is close to 1 in higher permeable samples $(>1000 \mathrm{mD})$, and lower in low permeable samples. Samples over $100 \mathrm{mD}$ show ratios above 0.2 , while only samples below $10 \mathrm{mD}$ showed ratios of 0.1 or below, which is the standard industry assumption for permeability modelling in the subsurface. Additional research on a larger data set may aid in better statistical constraining horizontal and vertical permeability in fluvio-eolian sandstones. 
Supplementary Information The online version contains supplementary material available at https://doi.org/10.1007/s00531-021-02036-6.

Acknowledgements Editor-in-Chief W.-C. Dullo is thanked for the editorial handling of this manuscript. R. Gaupp (University of Jena) and one anonymous reviewer are thankfully acknowledged for their constructive comments. The municipality of Cornberg is thanked for access to the quarry and logistical assistance. Cumbria Quarry Services Ltd. is thanked for access and logistical support. Access to the Schwentesius quarry and the decommissioned quarry in Bebertal on private property is thankfully acknowledged. D. Soyk and S. Kuchling (DGMK) are thanked for general administrative project coordination.

Funding Open Access funding enabled and organized by Projekt DEAL. We thankfully acknowledge research funding by the BMBF (Federal Ministry of Education and Research, research grant: FKZ 03G0868A).

Availability of data and materials All data is available within this article and its supplementary material.

\section{Declarations}

Conflict of interest The authors declare that there is no conflict of interests.

Open Access This article is licensed under a Creative Commons Attribution 4.0 International License, which permits use, sharing, adaptation, distribution and reproduction in any medium or format, as long as you give appropriate credit to the original author(s) and the source, provide a link to the Creative Commons licence, and indicate if changes were made. The images or other third party material in this article are included in the article's Creative Commons licence, unless indicated otherwise in a credit line to the material. If material is not included in the article's Creative Commons licence and your intended use is not permitted by statutory regulation or exceeds the permitted use, you will need to obtain permission directly from the copyright holder. To view a copy of this licence, visit http://creativecommons.org/licenses/by/4.0/.

\section{References}

Aagaard P, Egeberg PK, Saigal G, Morad S, Bjørlykke K (1990) Diagenetic albitization of detrital K-feldspars in Jurassic, Lower Cretaceous and Tertiary clastic reservoir rocks from offshore Norway; II, formation water chemistry and kinetic considerations. J Sediment Res 60:575-581. https://doi.org/10.1306/212F9 1EC-2B24-11D7-8648000102C1865D

Aagaard P, Jahren JS, Harstad AO, Nilsen O (2000) Formation of grain-coating chlorite in sandstones. Laboratory synthesized vs natural occurrences. Clay Miner 35:261-269

Aehnelt M, Katzung G (2007) Das Rotliegende im Richelsdorfer Gebirge-Stratigraphie, Lithologie und Paläogeographie. Geol Jb Hessen 134:5-36

Ajdukiewicz JM, Larese RE (2012) How clay grain coats inhibit quartz cement and preserve porosity in deeply buried sandstones: observations and experiments. AAPG Bull 96:2091-2119. https://doi. org/10.1306/02211211075

Ajdukiewicz JM, Nicholson PH, Esch WL (2010) Prediction of deep reservoir quality using early diagenetic process models in the Jurassic Norphlet Formation, Gulf of Mexico. AAPG Bull 94:1189-1227. https://doi.org/10.1306/04211009152
Ambrose WA, Lakshminarasimhan S, Holtz MH, Núñez-López V, Hovorka SD, Duncan I (2008) Geologic factors controlling CO2 storage capacity and permanence: case studies based on experience with heterogeneity in oil and gas reservoirs applied to $\mathrm{CO} 2$ storage. Environ Geol 54:1619-1633. https://doi.org/10.1007/ s00254-007-0940-2

Arthurton RS, Wadge AJ (1981) Geology of the country around Penrith vol 24. Institute of Geological Sciences, Natural Environment Research Council

Barnes DA, Bacon DH, Kelley SR (2009) Geological sequestration of carbon dioxide in the Cambrian Mount Simon Sandstone: regional storage capacity, site characterization, and large-scale injection feasibility. Mich Basin Environ Geosci 16:163-183. https://doi.org/10.1306/eg.05080909009

Becker I, Wüstefeld P, Koehrer B, Felder M, Hilgers C (2017) Porosity and permeability variations in a tight gas sandstone reservoir analogue, Westphalian D, Lower Saxony Basin, NW Germany: influence of depositional setting and diagenesis. J Pet Geol 40:363-390. https://doi.org/10.1111/jpg.12685

Becker I, Busch B, Koehrer B, Adelmann D, Hilgers C (2019) Reservoir quality evolution of Upper Carboniferous (Westphalian) tight gas sandstones, Lower Saxony Basin, NW Germany. J Pet Geol 42:371-392. https://doi.org/10.1111/jpg.12742

Benson SM, Cole DR (2008) CO2 sequestration in deep sedimentary formations. Elements 4:325-331. https://doi.org/10.2113/gsele ments.4.5.325

Berger G, Lacharpagne J-C, Velde B, Beaufort D, Lanson B (1997) Kinetic constraints on illitization reactions and the effects of organic diagenesis in sandstone/shale sequences. Appl Geochem 12:23-35. https://doi.org/10.1016/S0883-2927(96)00051-0

Berner RA (1969) Goethite stability and the origin of red beds. Geochim Cosmochim Acta 33:267-273. https://doi.org/10.1016/ 0016-7037(69)90143-4

BGS (2020) The BGS lexicon of named rock units. British Geological Survey. https://www.bgs.ac.uk/lexicon/. Accessed 10 Jul 2020

Bjørlykke K (2006) Effects of compaction processes on stresses, faults, and fluid flow in sedimentary basins: examples from the Norwegian margin. Geol Soc Lond Spec Publ 253:359-379. https://doi. org/10.1144/GSL.SP.2006.253.01.19

Bjørlykke K, Høeg K (1997) Effects of burial diagenesis on stresses, compaction and fluid flow in sedimentary basins. Mar Pet Geol 14:267-276. https://doi.org/10.1016/S0264-8172(96)00051-7

Bjørlykke K, Jahren JS (2010) Sandstones and sandstone reservoirs. In: Bjørlykke K (ed) Petroleum geoscience. Springer, Berlin, Heidelberg, pp 113-140

Busch B (2020) Pilot study on provenance and depositional controls on clay mineral coatings in active fluvio-eolian systems, western USA. Sediment Geol 406:105721. https://doi.org/10.1016/j. sedgeo.2020.105721

Busch B, Hilgers C, Gronen L, Adelmann D (2017) Cementation and structural diagenesis of fluvio-aeolian Rotliegend sandstones, northern England. J Geol Soc 174:855-868. https://doi.org/10. 1144/jgs2016-122

Busch B, Hilgers C, Lander RH, Bonnell LM, Adelmann D (2018) Reservoir quality and burial model evaluation by kinetic quartz and illite cementation modeling: case study of Rotliegendes, north Germany. AAPG Bull 102:293-307. https://doi.org/10. 1306/0503171605217075

Busch B, Becker I, Koehrer K, Adelmann D, Hilgers C (2019) Porosity evolution of two Upper Carboniferous tight-gas-fluvial sandstone reservoirs: impact of fractures and total cement volumes on reservoir quality. Mar Pet Geol 100:376-390. https://doi.org/ 10.1016/j.marpetgeo.2018.10.051

Busch B, Hilgers C, Adelmann D (2020) Reservoir quality controls on Rotliegend fluvio-aeolian wells in Germany and the Netherlands, Southern Permian Basin-impact of grain coatings and cements. 
Mar Pet Geol 112:104075. https://doi.org/10.1016/j.marpetgeo. 2019.104075

Cannon S (2018) Reservoir modelling: a practical guide. Wiley Blackwell, Chichester

Caulk RA, Tomac I (2017) Reuse of abandoned oil and gas wells for geothermal energy production. Renew Energy 112:388-397. https://doi.org/10.1016/j.renene.2017.05.042

Chan MA, Parry WT, Bowman JR (2000) Diagenetic hematite and manganese oxides and fault-related fluid flow in Jurassic Sandstones. Southeast Utah AAPG Bull 84:1281-1310. https://doi. org/10.1306/A9673E82-1738-11D7-8645000102C1865D

Clauer N, Liewig N, Zwingmann H (2012) Time-constrained illitization in gas-bearing Rotliegende (Permian) sandstones from northern Germany by illite potassium-argon dating. AAPG Bull 96:519-543. https://doi.org/10.1306/07131111003

Cohen KM, Finney SC, Gibbard PL, Fan J-X (2013) The ICS international chronostratigraphic chart. Episodes 36:199-204. https://doi.org/10.18814/epiiugs/2013/v36i3/002

dos Anjos SMC, De Ros LF, de Souza RS, de Assis Silva CM, Sombra CL (2000) Depositional and diagenetic controls on the reservoir quality of Lower Cretaceous Pendencia sandstones, Potiguar rift basin, Brazil. AAPG Bull 84:1719-1742. https:// doi.org/10.1306/8626C375-173B-11D7-8645000102C1865D

Ehrenberg SN (1990) Relationship between diagenesis and reservoir quality in sandstones of the Garn Formation, Haltenbanken, Mid-Norwegian Continental Shelf1. AAPG Bull 74:15381558. https://doi.org/10.1306/0C9B2515-1710-11D7-86450 $00102 \mathrm{C} 1865 \mathrm{D}$

Ehrenberg SN, Nadeau PH (1989) Formation of diagenetic illite in sandstones of the Garn Formation, Haltenbanken area, MidNorwegian continental shelf. Clay Miner 24:233-253. https:// doi.org/10.1180/claymin.1989.024.2.09

Esch WL, Ajdukiewicz JM, Reynolds AC (2008) Early grain-coat formation in Chaco dune field, New Mexico: insight into formation mechanisms, distribution, and implications for predictive modeling to assist in deep play identification. AAPG Annual Convention

Farrell NJC, Healy D (2017) Anisotropic pore fabrics in faulted porous sandstones. J Struct Geol 104:125-141. https://doi.org/ 10.1016/j.jsg.2017.09.010

Farrell NJC, Healy D, Taylor CW (2014) Anisotropy of permeability in faulted porous sandstones. J Struct Geol 63:50-67. https:// doi.org/10.1016/j.jsg.2014.02.008

Fischer C, Dunkl I, von Eynatten H, Wijbrans JR, Gaupp R (2012) Products and timing of diagenetic processes in Upper Rotliegend sandstones from Bebertal (North German Basin, Parchim Formation, Flechtingen High, Germany). Geol Mag 149:827840. https://doi.org/10.1017/S0016756811001087

Folk RL (1980) Petrology of the sedimentary rocks. Hemphill Publishing Company, Austin, Texas. https://doi.org/10.1016/0169555X(91)90027-8

Folk RL, Pittman JS (1971) Length-slow chalcedony; a new testament for vanished evaporites. J Sediment Res 41:1045-1058. https://doi.org/10.1306/74D723F1-2B21-11D7-8648000102 C1865D

Fossen H, Schultz RA, Torabi A (2011) Conditions and implications for compaction band formation in the Navajo Sandstone, Utah. J Struct Geol 33:1477-1490. https://doi.org/10.1016/j. jjg.2011.08.001

Gaitzsch B, Ellenberg J, Lützner H, Benek R (1995) Stratigraphie des Rotliegend in Oberflächenaufschlüssen-Flechtinger Scholle. In: Plein E (ed) Stratigraphie von Deutschland I: Norddeutsches Rotliegendbeckken, vol 183. Courier Forschungsinstitut Senckenberg, pp 84-96

Gaitzsch B, Geißler M, Göthel M, Kopp J, Legler B (2004) Karbon und Rotliegend der Flechtingen-Roßlau-Scholle. In: Friedel
C-H, Röhling H-G (eds) GeoLeipzig 2004-Geowissenschaften sichern Zukunft, vol 35. Deutsche Geologische Gesellschaft, Hannover, pp 150-164

Gast RE (1994) Cornberg outcrops revisited (Hessen, Germany): the depositional environment of its saurian tracks and Weissliegend Sandstones. Meyniana 46:59-75

Gast RE et al (2010) Rotliegend. In: Doornenbaal H, Stevenson A (eds) Petroleum geological atlas of the Southern Permian Basin Area. EAGE, Houten, pp 101-121

Gaupp R, Okkerman JA (2011) Diagenesis and reservoir quality of Rotliegend sandstones in the northern Netherlands, a review. SEPM Spec Publ 98:193-226. https://doi.org/10.2110/pec.11.98.0193

Gaupp R, Matter A, Platt J, Ramseyer K, Walzebuck J (1993) Diagenesis and fluid evolution of deeply buried Permian (Rotliegende) gas reservoirs, northwest Germany. AAPG Bull. https://doi.org/ 10.1306/BDFF8E0C-1718-11D7-8645000102C1865D

Gibbons K, Halvorsen C, Siring E (1993) Vertical and horizontal permeability variation within a sandstone reservoir based on minipermeameter measurements. Mar Pet Geol 10:325-334. https:// doi.org/10.1016/0264-8172(93)90077-6

Greene GW, Kristiansen K, Meyer EE, Boles JR, Israelachvili JN (2009) Role of electrochemical reactions in pressure solution. Geochim Cosmochim Acta 73:2862-2874. https://doi.org/10. 1016/j.gca.2009.02.012

Griffiths J, Worden RH, Woolridge LJ, Utley JEP, Duller RA (2019) Compositional variation in modern estuarine sands: predicting major controls on sandstone reservoir quality. AAPG Bull 103:797-833. https://doi.org/10.1306/09181818025

Haubold H, Lockley MG, Hunt AP, Lucas SG (1995) Lacertoid footprints from Permian dune sandstones, Cornberg and DeChelly sandstones. Early Permian foot-prints and facies. New Mexico Museum Nat Hist Sci Bull 6:235-244

Heap MJ (2019) The influence of sample geometry on the permeability of a porous sandstone. Geosci Instrum Methods Data Syst 8:55-61. https://doi.org/10.5194/gi-8-55-2019

Heap MJ, Kushnir ARL, Gilg HA, Wadsworth FB, Reuschlé T, Baud $P$ (2017) Microstructural and petrophysical properties of the Permo-Triassic sandstones (Buntsandstein) from the Soultz-sousForêts geothermal site (France). Geotherm Energy 5:26. https:// doi.org/10.1186/s40517-017-0085-9

Heidsiek M, Butscher C, Blum P, Fischer C (2020) Small-scale diagenetic facies heterogeneity controls porosity and permeability pattern in reservoir sandstones. Environ Earth Sci 79:425. https:// doi.org/10.1007/s12665-020-09168-Z

Heinemann N, Wilkinson M, Pickup GE, Haszeldine RS, Cutler NA (2012) CO2 storage in the offshore UK Bunter Sandstone Formation. Int J Greenhouse Gas Control 6:210-219. https://doi.org/ 10.1016/j.ijggc.2011.11.002

Henkel S, Pudlo D, Gaupp R, H2STORE-Team (2013) Research sites of the H2STORE project and the relevance of lithological variations for hydrogen storage at depths. Energy Procedia 40:25-33. https://doi.org/10.1016/j.egypro.2013.08.004

Houseknecht DW (1987) Assessing the relative importance of compaction processes and cementation to reduction of porosity in sandstones. AAPG Bull 71:633-642. https://doi.org/10.1306/ 9488787F-1704-11D7-8645000102C1865D

Huang W-L, Longo JM, Pevear DR (1993) An experimentally derived kinetic model for smectite-to-illite conversion and its use as a geothermometer. Clays Clay Miner 41:162-177. https://doi.org/ 10.1346/CCMN.1993.0410205

Hurst A, Nadeau PH (1995) Clay microporosity in reservoir sandstones: an application of quantitative electron microscopy in petrophysical evaluation. AAPG Bull 79:563-573. https://doi. org/10.1306/8D2B1598-171E-11D7-8645000102C1865D 
Iheanacho PC, Tiab D, Igbokoyi AO (2012) Vertical-horizontal permeability relationships for sandstone reservoirs In: SPE Nigeria Annual International Conference and Exhibition, Lagos, Nigeria. https://doi.org/10.2118/163011-MS

Jackson DI, Johnson H, Smith NJP (1997) Stratigraphical relationships and a revised lithostratigraphical nomenclature for the Carboniferous, Permian and Triassic rocks of the offshore East Irish Sea Basin. Geol Soc Lond Spec Publ 124:11-32. https:// doi.org/10.1144/GSL.SP.1997.124.01.02

Ketzer JM, Morad S, Amorosi A (2003) Predictive diagenetic claymineral distribution in siliciclastic rocks within a sequence stratigraphic framework. Int Assoc Sedimentol Spec Publ 34:43-61. https://doi.org/10.1002/9781444304336.ch2

Kley J, Voigt T (2008) Late Cretaceous intraplate thrusting in central Europe: Effect of Africa-Iberia-Europe convergence, not Alpine collision. Geology 36:839-842. https://doi.org/10.1130/ G24930A.1

Klinkenberg LJ (1941) The permeability of porous media to liquids and gases. In: Drilling and production practice. American Petroleum Institute

Knauss KG, Wolery TJ (1988) The dissolution kinetics of quartz as a function of $\mathrm{pH}$ and time at $70^{\circ} \mathrm{C}$. Geochim Cosmochim Acta 52:43-53. https://doi.org/10.1016/0016-7037(88)90055-5

Kohlhepp B (2012) Untersuchungen zu Fazies, Diagenese und Poren-/Mineralgrenzflächen an Rotliegend-Sandsteinen im Rahmen einer Analogstudie zur Wirkung von CO2 auf Gasspeichersysteme. Friedrich-Schiller-Universität Jena

Kowalczyk G, Herbst A, Heggemann H (2012) Rotliegend in den Hessischen Becken. In: Lützner H, Kowalczyk G (eds) Stratigraphie von Deutschland X. Rotliegend. Teil I: Innervariscische Becken., vol 61. Deutsche Gesellschaft für Geowissenschaften, Hannover, pp 378-417. https://doi.org/10.1127/sdgg/61/2012/ 378

Kristiansen K, Valtiner M, Greene GW, Boles JR, Israelachvili JN (2011) Pressure solution - the importance of the electrochemical surface potentials. Geochim Cosmochim Acta 75:6882-6892. https://doi.org/10.1016/j.gca.2011.09.019

Kulick J, Leifeld D, Meisl S (1984) Petrofazielle und chemische Erkundung des Kupferschiefers-der Hessischen Senke und des Harz-Westrandes. vol D 68. Geologisches Jahrbuch Reihe D. Schweizerbart, Hannover

Kunkel C, Aehnelt M, Pudlo D, Kukowski N, Totsche KU, Gaupp R (2018) Subsurface aquifer heterogeneities of Lower Triassic clastic sediments in central Germany. Mar Pet Geol 97:209-222. https://doi.org/10.1016/j.marpetgeo.2018.06.022

Kushnir ARL, Heap MJ, Baud P (2018) Assessing the role of fractures on the permeability of the Permo-Triassic sandstones at the Soultz-sous-Forêts (France) geothermal site. Geothermics 74:181-189. https://doi.org/10.1016/j.geothermics.2018.03.009

Lander RH, Bonnell LM (2010) A model for fibrous illite nucleation and growth in sandstones. AAPG Bull 94:1161-1187. https://doi. org/10.1306/04211009121

Lander RH, Larese RE, Bonnell LM (2008) Toward more accurate quartz cement models: the importance of euhedral versus noneuhedral growth rates. AAPG Bull 92:1537-1563. https://doi. org/10.1306/07160808037

Lanson B, Beaufort D, Berger G, Bauer A, Cassagnabère A, Meunier A (2002) Authigenic kaolin and illitic minerals during burial diagenesis of sandstones: a review. Clay Miner 37:1-22. https:// doi.org/10.1180/0009855023710014

Legler B, Schneider JW (2008) Marine ingressions into the Middle/ Late Permian saline lake of the Southern Permian Basin (Rotliegend, Northern Germany) possibly linked to sea-level highstands in the Arctic rift system. Palaeogeogr Palaeoclimatol Palaeoecol 267:102-114. https://doi.org/10.1016/j.palaeo.2008.06.009
Liewig N, Clauer N (2000) K-Ar dating of varied microtextural illite in Permian gas reservoirs, northern Germany. Clay Miner 35:271281. https://doi.org/10.1180/000985500546648

Lohr T et al (2007) Strain partitioning due to salt: insights from interpretation of a 3D seismic data set in the NW German Basin. Basin Res 19:579-597. https://doi.org/10.1111/j.1365-2117. 2007.00338.x

Lundegard PD (1992) Sandstone porosity loss; a "big picture" view of the importance of compaction. J Sediment Petrol 62:250-260. https://doi.org/10.1306/D42678D4-2B26-11D7-8648000102 C1865D

Macchi LC (1981) Sedimentology of the Penrith sandstone and Brockrams (Permo-Triassic) of Cumbria, north-west England. University of Hull, Hull

Mader D, Yardley MJ (1985) Migration, modification and merging in aeolian systems and the significance of the depositional mechanisms in Permian and Triassic dune sands of Europe and North America. Sed Geol 43:85-218. https://doi.org/10.1016/00370738(85)90056-9

Mahmic O, Dypvik H, Hammer E (2018) Diagenetic influence on reservoir quality evolution, examples from Triassic conglomerates/ arenites in the Edvard Grieg field, Norwegian North Sea. Mar Pet Geol 93:247-271. https://doi.org/10.1016/j.marpetgeo.2018. 03.006

Matlack KS, Houseknecht DW, Applin KR (1989) Emplacement of clay into sand by infiltration. J Sediment Res 59:77-87. https:// doi.org/10.1306/212F8F21-2B24-11D7-8648000102C1865D

McKinley JM, Worden RH, Ruffell AH (1999) Smectite in sandstones: a review of the controls on occurrence and behaviour during diagenesis. Int Assoc Sedimentol Spec Publ 34:109-128. https:// doi.org/10.1002/9781444304336.ch5

McKinley JM, Atkinson PM, Lloyd CD, Ruffell AH, Worden RH (2011) How porosity and permeability vary spatially with grain size, sorting, cement volume, and mineral dissolution in fluvial triassic sandstones: the value of geostatistics and local regression. J Sediment Res 81:844-858. https://doi.org/10.2110/jsr. 2011.71

Menning M (1995) A numerical time scale for the Permian and Triassic periods: an integrated time analysis. In: Scholle PA, Peryt TM, Ulmer-Scholle DS (eds) The Permian of Northern Pangea vol Volume 1: paleogeography, paleoclimates, stratigraphy. Springer, Berlin, Heidelberg. https://doi.org/10.1007/ 978-3-642-78593-1_6

Menning M et al (2011) Beschlüsse der Deutschen Stratigraphischen Kommission 1991-2010 zu Perm und Trias von Mitteleuropa. Zeitschrift der Deutschen Gesellschaft für Geowissenschaften 162:1-18. https://doi.org/10.1127/1860-1804/2011/0162-0001

Meyer R (2002) Anisotropy of sandstone permeability. CREWES Res Rep 14:1-12

Milliken KL (1992) Chemical behavior of detrital feldspars in mudrocks versus sandstones, Frio Formation (Oligocene), South Texas. J Sediment Res 65:790-801. https://doi.org/10.1306/ D42679DD-2B26-11D7-8648000102C1865D

Molenaar N, Felder M (2018) Clay cutans and the origin of Illite Rim cement: an example from the Siliciclastic Rotliegend Sandstone in the Dutch Southern Permian Basin. J Sediment Res 88:641658. https://doi.org/10.2110/jsr.2018.33

Monsees AC, Busch B, Schöner N, Hilgers C (2020a) Rock typing of diagenetically induced heterogeneities - a case study from a deeply-buried clastic Rotliegend reservoir of the Northern German Basin. Mar Petrol Geol 113:104163. https://doi.org/10. 1016/j.marpetgeo.2019.104163

Monsees AC, Subhedar A, Busch B, Nestler B, Hilgers C (2020b) Calibrating micro-computed tomography data to permeability experiments and petrography_insights from Digital Rocks. OIL GAS Eur Mag 70:28-33 
Morad S (1998) Carbonate cementation in sandstones: distribution patterns and geochemical evolution. Spec Publ Int Assoc Sediment 26:1-26. https://doi.org/10.1002/9781444304893

Morad S, Al-Ramadan K, Ketzer JM, De Ros LF (2010) The impact of diagenesis on the heterogeneity of sandstone reservoirs: a review of the role of depositional facies and sequence stratigraphy. AAPG Bull 94:1267-1309. https://doi.org/10.1306/ 04211009178

Motzka-Nöring R et al (1987) Erläuterungen zur Geologischen Karte von Hessen 1:25000 Blatt Nr. 4925 Sontra, 2nd edn. Hessisches Landesamt für Bodenforschung, Wiesbaden

Otto V (2003) Inversion-related features along the southeastern margin of the North German Basin (Elbe Fault System). Tectonophysics 373:107-123. https://doi.org/10.1016/S0040-1951(03) 00287-7

Paul J (2012) Weißliegend, Grauliegend und das Zechstein-Konglomerat: die Rotliegend/Zechstein-Grenze. In: Lützner H, Kowalczyk G (eds) Stratigraphie von Deutschland X. Rotliegend. Teil I: Innervariscische Becken, vol 61. Deutsche Gesellschaft für Geowissenschaften, Hannover, pp 707-714

Paxton ST, Szabo JO, Ajdukiewicz JM, Klimentidis RE (2002) Construction of an intergranular volume compaction curve for evaluating and predicting compaction and porosity loss in rigid-grain sandstone reservoirs. AAPG Bull 86:2047-2067. https://doi.org/ 10.1306/61EEDDFA-173E-11D7-8645000102C1865D

Pfeiffer WT, Beyer C, Bauer S (2017) Hydrogen storage in a heterogeneous sandstone formation: dimensioning and induced hydraulic effects. Pet Geosci 23:315-326. https://doi.org/10.1144/petge o2016-050

Pittman ED, Larese RE, Heald MT (1992) Clay coats: occurrence and relevance to preservation of porosity in sandstones. SEPM Spec Publ 47:241-255. https://doi.org/10.2110/pec.92.47.0241

Prajapati N, Selzer M, Nestler B, Busch B, Hilgers C, Ankit K (2018) Three-dimensional phase-field investigation of pore space cementation and permeability in quartz sandstone. JGR Solid Earth 123:6378-6396. https://doi.org/10.1029/2018JB015618

Prajapati N, Abad Gonzalez A, Selzer M, Nestler B, Busch B, Hilgers C (2020) Quartz cementation in polycrystalline sandstone: insights from phase-field simulations. JGR Solid Earth. https://doi.org/ 10.1029/2019JB019137

Pryor AW (1971) Petrology of the Weißliegendes sandstones in the Harz and Werra-Fulda area. Geol Rundsch 80:524-552. https:// doi.org/10.1007/BF02000468

Salem AM, Morad S, Mato LF, Al-Aasm IS (2000) Diagenesis and reservoir-quality evolution of fluvial sandstones during progressive burial and uplift: evidence from the Upper Jurassic Boipeba Member, Reconcavo basin, northeastern Brazil. AAPG Bull 84:1015-1040. https://doi.org/10.1306/A9673B9E-1738-11D7$8645000102 \mathrm{C} 1865 \mathrm{D}$

Scheck M, Bayer U, Otto V, Lamarche J, Banka D, Pharaoh T (2002) The Elbe Fault System in North Central Europe-a basement controlled zone of crustal weakness. Tectonophysics 360:281299. https://doi.org/10.1016/S0040-1951(02)00357-8

Schmid S, Worden RH, Fisher QJ (2004) Diagenesis and reservoir quality of the Sherwood Sandstone (Triassic), Corrib Field, Slyne Basin, west of Ireland. Mar Pet Geol 21:299-315. https:// doi.org/10.1016/j.marpetgeo.2003.11.015

Schmidt C, Busch B, Hilgers C (2020a) Compaction and cementation control on bleaching in Triassic fluvial red beds, S-Germany. Zeitschrift der Deutschen Gesellschaft für Geowissenschaften. https://doi.org/10.1127/zdgg/2020/0233

Schmidt C, Busch B, Hilgers C (2020b) Lateral variations of detrital, authigenic and petrophysical properties in an outcrop analog of the fluvial Plattensandstein, Lower Triassic, Central S-Germany. Z Dt Ges Geowiss. https://doi.org/10.1127/zdgg/2020/0234
Schneider J, Gebhardt U (1993) Litho- und Biofaziesmuster in intraund extramontanen Senken des Rotliegend (Perm, Nord- und Ostdeutschland). Geologisches Jahrbuch Reihe A 131:57-98

Schröder L et al (1995) Stratigraphische Neugliederung des Rotliegend im Norddeutschen Becken. Geologisches Jahrbuch Reihe A $148: 3-21$

Schumacher C (1985) Die Kupfervererzungen des basalen Zechsteins im Rahmen der sedimentären Entwicklung des Werra-FuldaBeckens. FU Berlin

Schwarzer D, Littke R (2007) Petroleum generation and migration in the 'Tight Gas' area of the German Rotliegend natural gas play: a basin modelling study. Pet Geosci 13:37-62. https://doi.org/10. 1144/1354-079306-703

Shepherd RG (1989) Correlations of permeability and grain size. Groundwater 27:633-638. https://doi.org/10.1111/j.1745-6584. 1989.tb00476.x

Stollhofen H et al (2008) Upper Rotliegend to Early Cretaceous basin development. In: Littke R, Bayer U, Gajewski S, Nelskamp S (eds) Dynamics of complex intracontinental basins. The Central European Basin System. Springer, Berlin, Heidelberg, pp 181-210. https://doi.org/10.1007/978-3-540-85085-4_4

Storvoll V, Bjørlykke K, Karlsen D, Saigal G (2002) Porosity preservation in reservoir sandstones due to grain-coating illite: a study of the Jurassic Garn Formation from the Kristin and Lavrans fields, offshore Mid-Norway. Mar Pet Geol 19:767-781. https://doi.org/ 10.1016/S0264-8172(02)00035-1

Tada R, Siever R (1989) Pressure solution during diagenesis. Annu Rev Earth Planet Sci 17:89-118. https://doi.org/10.1146/annur ev.ea.17.050189.000513

Taylor TR et al (2010) Sandstone diagenesis and reservoir quality prediction: models, myths, and reality. AAPG Bull 94:1093-1132. https://doi.org/10.1306/04211009123

Trask PD (1930) Mechanical analyses of sediments by centrifuge. Econ Geol 25:581-599. https://doi.org/10.2113/gsecongeo.25.6.581

Turner P, Burley SD, Rey D, Prosser J (1995) Burial history of the Penrith Sandstone (Lower Permian) deduced from the combined study of fluid inclusion and palaeomagnetic data. In: Turner P, Turner A (eds) Palaeomagnetic applications in hydrocarbon exploration and production, vol 98. Geol Soc Spec Publ, pp 43-78. https://doi.org/10.1144/GSL.SP.1995.098.01.04

Underhill JR, Gayer RA, Woodcock NH, Donnely R, Jolley EJ, Stimpson IG (1988) The Dent Fault System, northern England-reinterpreted as a major oblique-slip fault zone. J Geol Soc Lond 145:303-316. https://doi.org/10.1144/gsjgs.145.2.0303

van Houten FB (1973) Origin of red beds-a review-1961-1972. Annu Rev Earth Planet Sci 1:39-61. https://doi.org/10.1146/ annurev.ea.01.050173.000351

Vincent B, Waters J, Witkowski F, Daniau G, Oxtoby NH, Crowley S, Ellam R (2018) Diagenesis of Rotliegend sandstone reservoirs (offshore Netherlands): the origin and impact of dolomite cements. Sed Geol 373:272-291. https://doi.org/10.1016/j. sedgeo.2018.06.012

Wadsworth FB, Vasseur J, Scheu B, Kendrick JE, Lavallée Y, Dingwell DB (2016) Universal scaling of fluid permeability during volcanic welding and sediment diagenesis. Geology 44:219-222. https://doi.org/10.1130/G37559.1

Walderhaug O (1990) A fluid inclusion study of quartz-cemented sandstones from offshore mid-Norway; possible evidence for continued quartz cementation during oil emplacement. J Sediment Res 60:203-210. https://doi.org/10.1306/212F9151-2B24-11D7$8648000102 \mathrm{C} 1865 \mathrm{D}$

Walderhaug O (1994) Temperatures of quartz cementation in Jurassic sandstones from the Norwegian continental shelf-evidence from fluid inclusions. J Sediment Res 64:311-323. https://doi. org/10.1306/D4267D89-2B26-11D7-8648000102C1865D 
Walderhaug O, Bjørkum PA (2003) The effect of stylolite spacing on quartz cementation in the Lower Jurassic Stø Formation, southern Barents Sea. J Sediment Res 73:146-156. https://doi.org/10. 1306/090502730146

Walderhaug O, Lander RH, Bjørkum PA, Oelkers EH, Bjørlykke K, Nadeau PH (2000) Modelling Quartz Cementation and Porosity in Reservoir Sandstones: examples from the Norwegian Continental Shelf. Int Assoc Sedimentol Spec Publ 29:39-50. https:// doi.org/10.1002/9781444304237.ch3

Walker TR, Honea RM (1969) Iron content of modern deposits in the Sonoran Desert: a contribution to the origin of red beds GSA. Bulletin 80:535-544. https://doi.org/10.1130/0016-7606(1969) 80[535:ICOMDI]2.0.CO;2

Walker FDL, Lee MR, Parsons I (1995) Micropores and micropermeable texture in alkali feldspars: geochemical and geophysical implications. Mineral Mag 59:505-534. https://doi.org/10.1180/ minmag.1995.059.396.12

Waugh B (1970) Petrology, provenance and silica diagenesis of the Penrith Sandstone (Lower Permian) of Northwest England. J Sediment Petrol 40:1226-1240. https://doi.org/10.1306/74D72 171-2B21-11D7-8648000102C1865D

Waugh B (1970) Formation of quartz overgrowths in the Penrith Sandstone (Lower Permian) of Northwest England as revealed by scanning electron microscopy. Sedimentology 14:309-320. https://doi.org/10.1111/j.1365-3091.1970.tb00197.x

Whitaker S (1996) The Forchheimer equation: a theoretical development. Transp Porous Media 25:27-61. https://doi.org/10.1007/ BF00141261

Woodcock NH, Sayers NJ, Dickson JA (2008) Fluid flow history from damage zone cements near the Dent and Rawthey faults, NW England. J Geol Soc Lond 165:829-837. https://doi.org/10.1144/ 0016-76492007-133

Woolridge LJ, Worden RH, Griffiths J, Utley JEP (2017) Claycoated sand grains in petroleum reservoirs: understanding their distribution via a modern analogue. J Sediment Res 87:338-352. https://doi.org/10.2110/jsr.2017.20

Worden RH, Morad S (2003) Clay minerals in sandstones: controls on formation, distribution and evolution. Int Assoc Sedimentol Spec Publ 34:3-41. https://doi.org/10.1002/9781444304336.ch1

Worden RH et al (2018) Petroleum reservoir quality prediction : overview and contrasting approaches from sandstone and carbonate communities. Geol Soc Lond Spec Publ 435:1-31. https://doi. org/10.1144/SP435.21

Wüstefeld P, Hilse U, Lüders V, Wemmer K, Koehrer B, Hilgers C (2017) Kilometer-scale fault-related thermal anomalies in tight gas sandstones. Mar Pet Geol 86:288-303. https://doi.org/10. 1016/j.marpetgeo.2017.05.015

Yuan G et al (2015) Feldspar dissolution, authigenic clays, and quartz cements in open and closed sandstone geochemical systems during diagenesis: typical examples from two sags in Bohai Bay Basin, East China. AAPG Bull 99:2121-2154. https://doi.org/ 10.1306/07101514004

Ziegler PA (1990) Geological atlas of western and central Europe. Shell Internationale Petroleum Maatschappij B.V, The Hague

Ziegler K (2006) Clay minerals of the Permian Rotliegend Group in the North Sea and adjacent areas. Clay Miner 41:355-393. https:// doi.org/10.1180/0009855064110200

Zwingmann H, Clauer N, Gaupp R (1998) Timing of fluid flow in a sandstone reservoir of the north German Rotliegend (Permian) by K-Ar dating of related hydrothermal illite. Geol Soc Lond Spec Publ 144:91-106. https://doi.org/10.1144/GSL.SP.1998. 144.01 .07

Zwingmann H, Clauer N, Gaupp R (1999) Structure-related geochemical (REE) and isotopic (K-Ar, Rb-Sr, d18O) characteristics of clay minerals from Rotliegend sandstone reservoirs (Permian, northern Germany). Geochim Cosmochim Acta 63:2805-2823. https://doi.org/10.1016/S0016-7037(99)00198-2 